\title{
How Should the Irish State Respond to the Radicalisation of Irish Citizens in Support of Islamist Terrorism?
}

\section{Niall McCorry}

In spite of several high-profile cases of radicalisation in recent years, Ireland does not appear to have formulated a coherent response, unlike most other European countries. This paper aims to answer the central research question: how should the Irish state respond to the radicalisation of Irish citizens in support of Islamist terrorism?

A review of the literature on radicalisation was conducted, based upon the models of radicalisation set forth by Wiktorowicz (2004) and Precht (2007) which have identified possible indicators of radicalisation. As the literature on the subject is somewhat sparse relating to the Irish context, the counter-radicalisation strategies of the United Kingdom (UK) and Denmark were examined for international comparison.

The study was carried out as a qualitative, phenomenological research project using mixed methods. Documentary analysis of relevant Irish, UK, and Danish government publications was followed by the conduct of semi-structured elite interviews. It is apparent that this country does not have a proactive approach to security issues in general, and radicalisation in particular. Interviewees were strong in their support for the adoption of more clearly defined measures to counter Islamist radicalisation specific to the context in this country, though there is no clear consensus on the best path forward. The complex individual nature of the radicalisation process, and the impact of external influences, were recognised as key considerations. The need for widespread consultation, at the expert level, on the crafting of the state's response was also emphasised, given the risks involved in a poorly conceptualised approach. Community cohesion emerged as an important topic, and may form the basis for an effective response, along with training for appropriate professionals and sensitisation of the population to the dangers of the issue.

This paper examines how the Irish state should respond to the radicalisation of Irish citizens in support of Islamist terrorism. As the Islamic State group (IS) emerged from the carnage of the Syrian Civil War, the group became infamous for their barbarity and proved themselves highly proficient in the use of social media. Fighters and supporters were 
attracted from across the globe. These included a number from Ireland, some of whom fought while others claim to have fulfilled supporting roles. High-profile Irish cases include those of Khalid Kelly and Lisa Smith. Kelly, ultimately killed carrying out a suicide bombing for IS in Iraq, was a convert to Islam, advocate for a Salafist-jihadist interpretation of Sunni Islam and supporter of al-Qaeda and IS. Smith is a former member of the Defence Forces who was detained in the area formerly controlled by IS in March 2019. At the time of writing, she is facing trial on terrorism charges. The recent Global Terrorism Background Report (START, 2019) underlines the persistent threat from Islamist terrorism, spearheaded by the threat from IS. A cursory examination of the situation across Europe appears to suggest that Ireland is not as well prepared as other countries to meet this threat (European Commission, 2020). Therefore, further investigation and analysis is warranted.

Within the wider field of terrorism research, the study of radicalisation has grown to become a central focus following the terrorist attacks of 9/11, and in Europe following attacks in Madrid in 2004 and London in 2005 (Silke, 2008; Schmid, 2016). This paper aims to examine the Irish State's response to the complex issue of Islamist radicalisation. The central question of how the State should respond to the radicalisation of Irish citizens in support of Islamist terrorism is supported by three subordinate research questions:

- What indicators of radicalisation have been identified in existing models of radicalisation?

- How have these indicators been 'operationalised' in other countries?

- What measures can the Irish state take to address the problem of radicalisation in support of Islamist terrorism?

This paper employs a theoretical framework based on the models of radicalisation put forward by Wiktorowicz (2004) and Precht (2007). The factors and stages identified in these models are used to form a framework to analyse the counter-radicalisation approaches taken in Ireland, the United Kingdom (UK) and Denmark. This will provide structure for this paper and help to uncover in the first instance, if the State's response to Islamist radicalisation is fit for purpose; and if appropriate, to recommend improvements.

It is essential that the provisions which the state makes to provide for the security of its citizens are the subject of analysis and academic debate. International terrorism is identified as a security threat facing the State in the most recent White Paper on Defence Update (2019), and the issue has been raised in Dáil Éireann (Oireachtas na hÉireann, 2019). The White Paper Update (2019) refers to radicalisation of individuals in support of terrorist organisations through "the range of influences, including the internet, which can enable this process" (p. 32). And yet, unlike most other European Union member states, this country has no published strategies for national security, counterterrorism, or counterradicalisation (European Commission, 2020). There also appears to be a dearth of academic research into the subject of radicalisation which is specific to Ireland. These gaps give this research particular relevance.

\section{Structure}

Part One of this paper is a critical review of the existing literature on radicalisation and evaluates how the State can operationalise indicators of radicalisation in order to counter violent extremism and terrorism. Part Two then details the methodology utilised in the research. Part Three provides an analysis and discussion of the key findings based upon data collected before Part Four concludes by synthesising the findings and proposes recommendations for the State's approach to radicalisation. 


\section{PART ONE. Literature Review}

This review will evaluate the existing literature on the subject of radicalisation and develop a framework within which to analyse how Ireland, the UK and Denmark respond to the radicalisation of their citizens in support of Islamist terrorism. The first section will briefly explore the historical background to the concept of radicalisation within the field of terrorism studies, before moving on to examine two key models of radicalisation. Given the volume of literature on the subject of radicalisation, it was necessary to be selective, and accordingly the models developed by Wiktorowicz (2004) and Precht (2007) were chosen. Analysis of the debate around the concept of radicalisation and its relationship to extremist beliefs and terrorism, along with international comparisons, will facilitate a clearer understanding of how the Irish state should respond in future. It is appropriate to begin by exploring the historical context behind the study of radicalisation.

\section{Historical background}

The use of the term 'radicalised' or 'radicalisation' in relation to terrorism studies is relatively new, having emerged following the 11 September, 2001 attacks on the United States (Silke, 2008). The use of the terms is often intended to provide a dramatic description of how a person came to support a cause which is viewed as 'bad' by the majority of society. Martha Crenshaw's influential 1981 paper The Causes of Terrorism only makes mention of the term 'radical' in reference to the desire for change by student protestors. As she sought to explain why terrorism occurs, she looked into "the setting for terrorism" and spoke about preconditions and precipitants (Crenshaw, 1981). As Coolsaet (2015) observes, "after 9/11, context, preconditions, and root causes took a back seat", as the emphasis for terrorism research shifted to the actions of the individual as opposed to the circumstances surrounding them (p. 6). The prioritisation of the study of radicalisation over investigation of the "enabling environment" is a weakness within the fields of radicalisation and terrorism studies, but also within national responses to those phenomena (Schmid, 2016, p. 26). Bearing this weakness in mind, this research does not seek to analyse the process of radicalisation, but rather to examine how the Irish state should respond to the issue and what impacts this might have on the wider society.

\section{The challenge of defining radicalisation}

Schmid (2013) outlines how academic commentary on radicalisation is still evolving and is hampered by a lack of empirical research and the absence of an agreed definition of radicalisation. Neumann (2008) considers it as "what goes on before the bomb goes off" (p. 4), but this succinct statement is controversial and simplistic to say the least. Mandel (2009) defines radicalisation as the "process whereby an originally moderate individual or group of individuals becomes progressively more extreme in their thinking, and possibly their behaviour, over time" (p. 107). This definition has merits; however, it could be argued that it is incomplete as it fails to make any reference to the nature of the process or the drivers behind it. Schmid (2013) posits that radicalisation

is not just a socio-psychological scientific concept but also a political construct, introduced into the public and academic debate mainly by national security establishments faced with political Islam in general and Salafist Jihadism in particular (p. 19). 
Schmid's (2013) definition very much places radicalisation within the realm of violent Islam and national security, but it is also weakened by the failure to take account of the individual, processive nature of radicalisation.

This paper will adopt, as a working definition of radicalisation, that of McCauley and Moskalenko (2011), who contend that radicalisation is "the development of beliefs, feelings, and actions in support of any group or cause in conflict" $(2011$, p. 4). This definition is considered appropriate for this research since it captures a number of key components which are broadly agreed upon by the academic community. Firstly, the inclusion of the term "development" indicates that the authors perceive radicalisation as a process, and not an "end-point" in itself (McCauley and Moskalenko, 2011, p. 4; Neumann, 2013, p. 874). Secondly, it emphasises that radicalisation occurs within the individual as a psychological process (Horgan, 2008). Thirdly, that the process occurs due to external influences due to the beliefs of a group in conflict indicates the adversarial nature of the dynamic within the mind of the individual (Neumann, 2013). McCauley and Moskalenko (2011) also acknowledge that an extreme of radicalisation is terrorism, in which a non-state group can act to target not only government forces but civilian citizens supporting the government.

\section{The spectrum of radicalisation}

The idea that radicalisation leads to terrorism is fiercely contested in academic circles. Dr. John Horgan (quoted in Knefel, 2013) asserts that:

the idea that radicalisation causes terrorism is perhaps the biggest myth alive today in terrorism...[first], the overwhelming majority of people who hold radical beliefs do not engage in violence. And second, there is increasing evidence that people who engage in terrorism don't necessarily hold radical beliefs (p. 2).

Thus, not only is there a lack of an agreed definition, but the link between radicalism and radicalisation is also misunderstood. Awan, Hoskins, and O'Loughlin (2012) point out that radicalism, the desire for sweeping political and social change, is a legitimate political objective for both left- and right-wing political parties. McCauley and Moskalenko (2008; 2011) draw upon a diverse set of examples and provide a comprehensive distinction between the process to legal political action as opposed to illegal, violent political actions.

A helpful contribution is provided by Neumann (2013: p. 873), who seeks to illustrate the differences in the European and North American approach to countering radicalisation by exploring the distinction between radicalisation focussed upon extremist beliefs ("cognitive radicalisation") and that which emphasises extremist behaviour ("behavioural radicalisation"). Neumann asserts that "at the most basic level, radicalisation can be defined as the process whereby people become extremists" but acknowledges that "radicalisation ... is inherently context-dependent, and its meaning will always be contested" (2013: p. 874-878). He proposes the idea of radicalisation and extremism as points on a spectrum. People are not radicalised overnight, nor is there a single identifiable cause; rather radicalisation occurs as a process, which evolves "over a period of time and involves different factors and dynamics" (Neumann, 2013, p. 874). He then examines a number of definitions put forward by academics and governments to illustrate the lack of agreement on the "end-point" of radicalisation (p. 874). Neumann's (2013) analysis is valid in explaining the background to and reasons for the differing approaches to radicalisation and counter radicalisation and will be returned to in a later section of this review. 


\section{Models of radicalisation}

King and Taylor (2011) use evidence from terrorism research and social psychology to analyse five major models of radicalisation. They identify three psychological themes which are common across the theories: relative deprivation, identity conflicts, and personality characteristics (p. 602). Relative deprivation is a fuel for injustice in the mind of the individual (or the minds of the collective group) at the early stages of radicalisation (King and Taylor, 2011). Conflicts of identity, which can relate to dissatisfaction with old answers and belief systems, and the striving for new ones can be especially apparent within second and third generation immigrants and converts to Islam (Choudhury, 2007). The third theme, personality characteristics, the presence of certain idiosyncratic predispositions in an individual, is identified by King and Taylor (2011) as being the least likely to facilitate individual radicalisation.

The research of Precht (2007) explores how factors from the individual's background interact with their environment and the people surrounding them. Precht's (2007) research is considered appropriate to this research and facilitates the extrapolation of recommendations for the Irish case, for a number of reasons. Firstly, it is framed within the ongoing threat to Europe from Islamist terrorism, often perpetrated by those who have grown up in Europe and who appear to have been integrated (Precht, 2007, p. 5). Secondly, it recognises the need to study the radicalisation not just of young Muslim men, but also Muslim women and converts. Thirdly, it places a particular focus not just on the individual, but also on the environment and influencing factors surrounding them.

Precht's (2007) model (depicted below as Figure 2.1.) emerged from research conducted in Denmark and the Netherlands which aimed to identify the phases, characteristics, and catalysts of the radicalisation process. He concluded that while there is no "common profile" and that no single factor can be considered "causal", there are many pathways (pp. 5-6). His research did identify specific phases of radicalisation: preradicalisation, conversion and identification with radical Islam, conviction and indoctrination, and actual acts of terrorism or planned plots (Precht, 2007, p. 5).

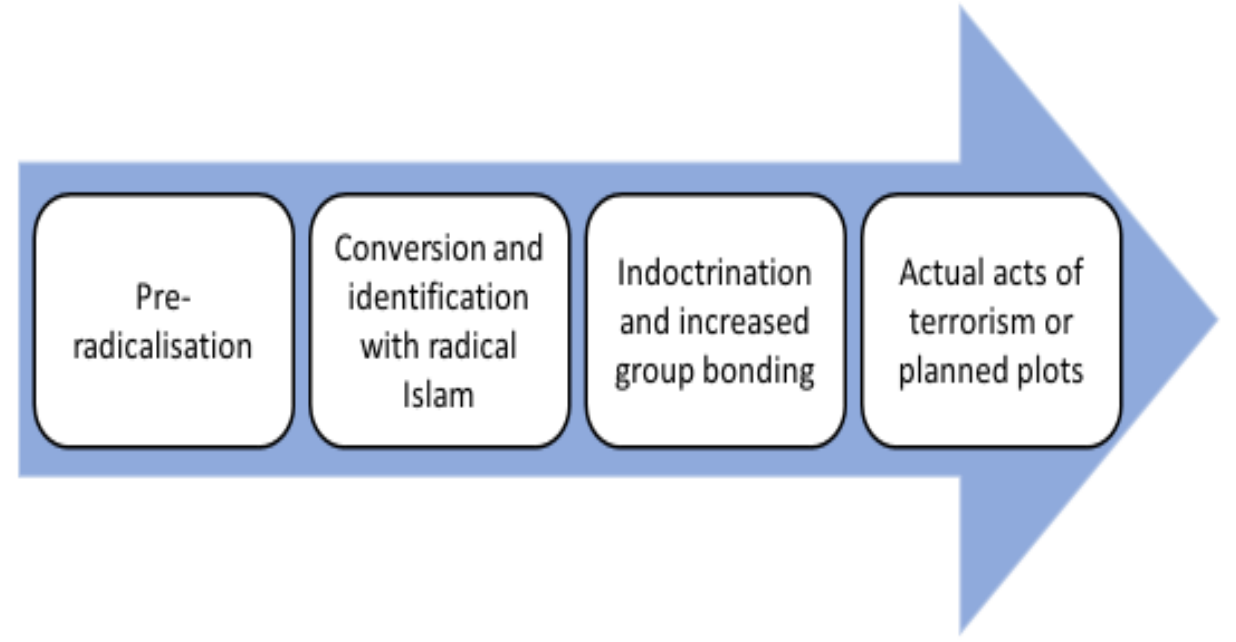

Figure 2.1. Precht's model of radicalisation (Borum, 2011, p. 42).

Across these four phases, three categories of factors are identified which explain the context and motivational factors which influence the radicalisation process and overlap the phases is described. The first category, "background factors", covers the search for personal and religious identity, discrimination, deprivation, and the living environment 
such as segregation, injustice, alienation (p. 38). The second category, "trigger factors" includes reactions to events such as Western military intervention in the Middle East, or people, for example the presence of a charismatic mentor (p. 38). The third category Precht calls "opportunity factors" which cover the possibility to interlink with likeminded people to reinforce the grievance or injustice of a particular struggle or conflict, either through sources of information, or face to face with individuals, or groups (for example, a mosque, university, school, café, prison) (p. 38).

The model of radicalisation developed by Wiktorowicz (2004) is illustrated in Figure 2.2. below. Within the context of the overarching environment, this model further refines the influence of the individual's search for identity by introducing the concept of a "cognitive opening", as the first part of a four-stage model of radicalisation (p. 1). The "cognitive opening" is when the individual is "receptive to the possibility of new ideas or a new worldview" and he argues that this can open a block on the pathway to radicalisation (Wiktorowicz, 2004, p. 1). Wiktorowicz' (2004) research was based upon a study conducted in the UK of the members of the transnational Islamist organisation, al-Muhajiroun. Wiktorowicz' (2004) model is especially pertinent to this paper not just because it provides a detailed insight into the context and rationale for joining a radical Islamist organisation. It has added significance given the well-publicised support for al-Muhajiroun by the Irish extremist Khalid Kelly. Kelly went on to become a prominent supporter of IS in Ireland and was killed carrying out a suicide bombing for IS in Iraq in 2016 (McMahon, 2016). Wiktorowicz' (2004) study is exceptional given the extraordinary level of access to members of al-Muhajiroun afforded to him.

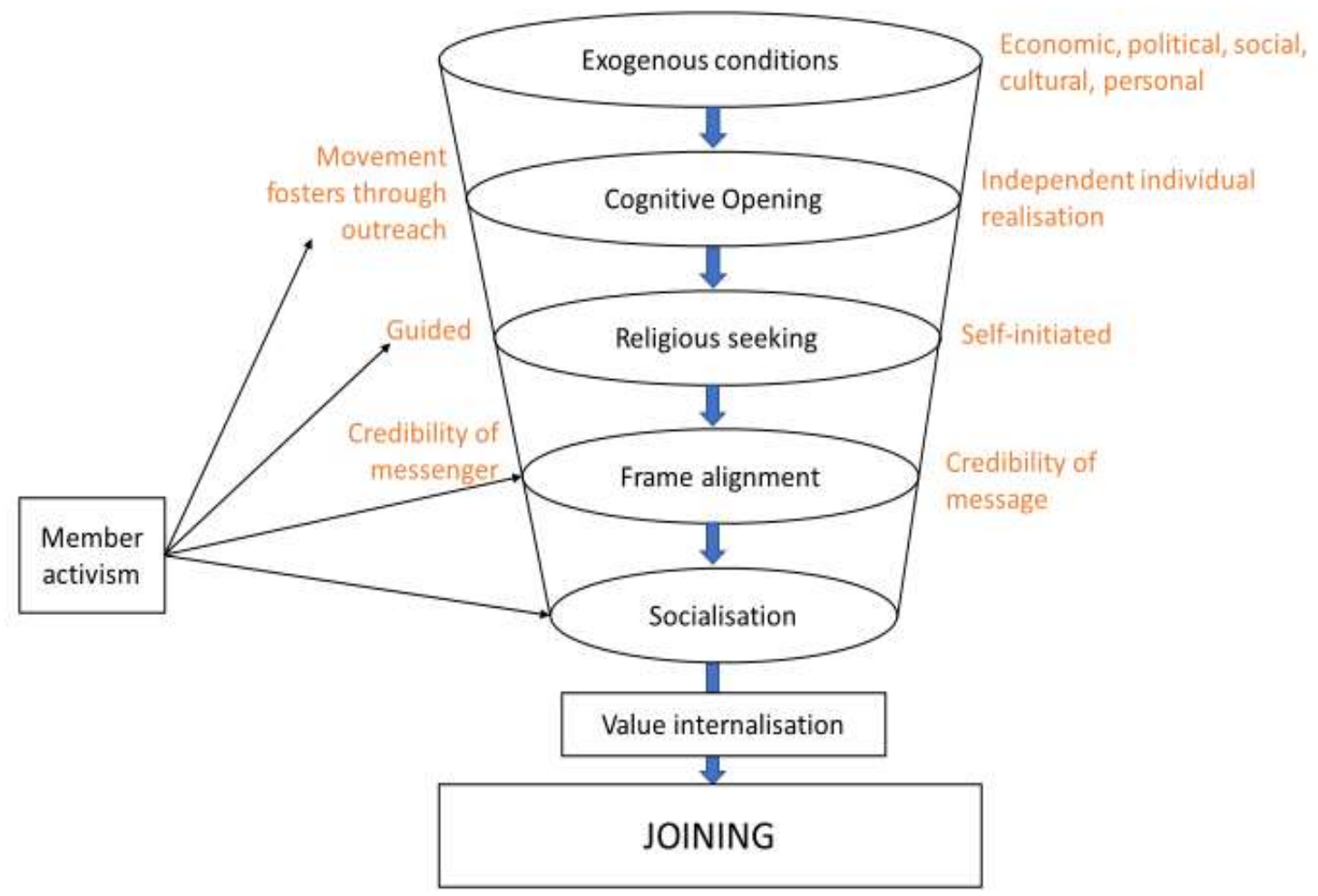

Figure 2.2. Wiktorowicz' model for joining extremist or terrorist groups (Schmid, 2013, p. 23).

Wiktorowicz (2004) found that since "a decision to join a radical Islamic movement seems irrational", persuasion must lie at the heart of the individuals' decision-making ( $p$. 
1). The "cognitive opening" occurs when the individual who is struggling with a "crisis" (which could be a personal difficulty, an incident, or a societal issue) is receptive to ideas that ordinarily they may have resisted (p. 1). The second stage, "religious seeking" follows, where the individual looks to religion for meaning to explain their life situation, and leads to the third stage, "frame alignment" (p. 1). This is where the individual feels that the public message of the group "makes sense" in that the Islamist view of the group aligns with the views of the individual (p. 1). This will include deference to the religious expertise of those influencing the individual (King and Taylor, 2011). The fourth stage, socialisation to the group, follows. In this stage, indoctrination is facilitated through religious lessons and activities, identity is reconstructed and values altered. A composite diagram which shows the models developed by Precht (2007) and Wiktorowicz (2004) is depicted in Figure 2.3 below. The diagram depicts the stages identified within each model and specifies the types of indicators which were apparent within the behaviour of individuals during each stage. Indicators such as these are used as a means of identifying persons at risk, particularly in Prevent (UK Government, 2011). The utility and suitability of the use of indicators will be examined in Part Three.

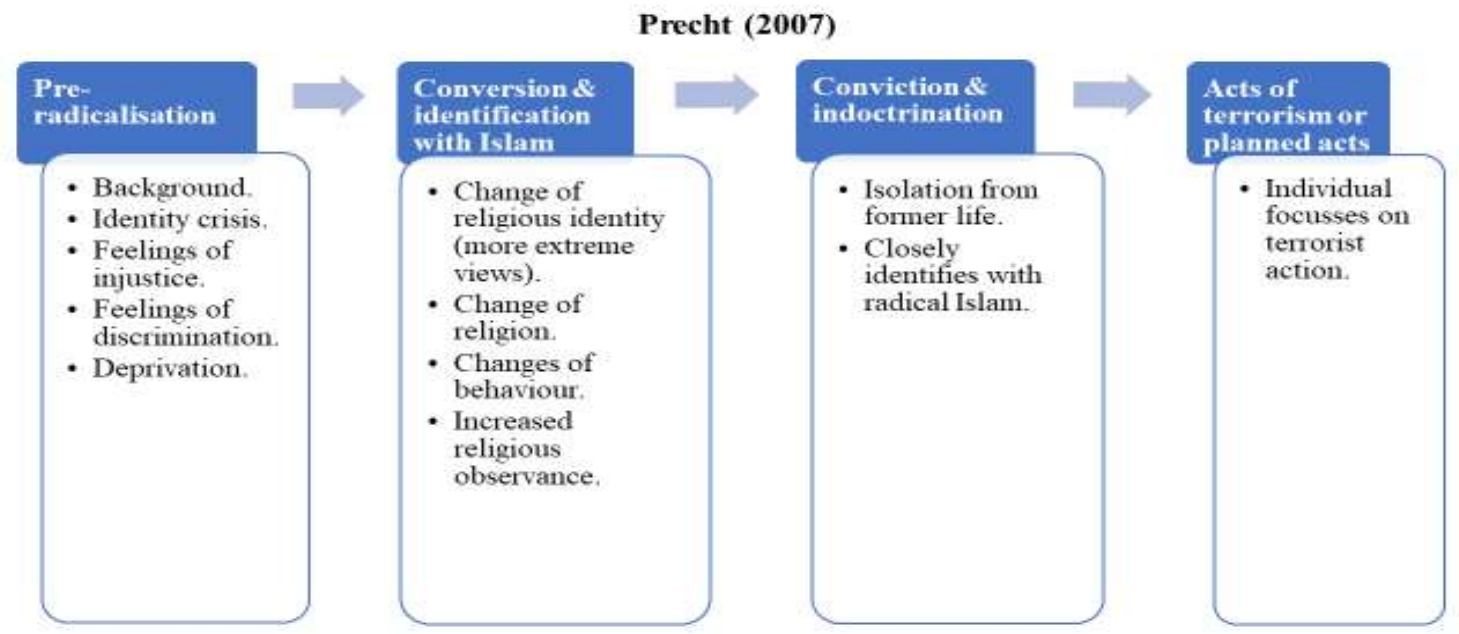

Wiktorowicz (2004)

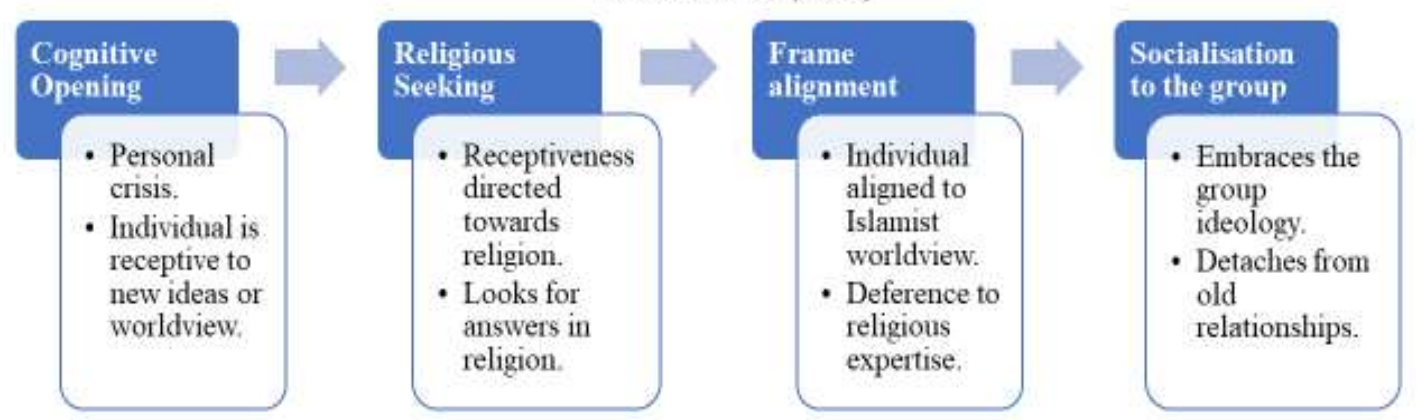

Figure 2.3. Summary of the Models of Radicalisation developed by Precht (2007) and Wiktorowicz (2004) showing potential indicators of radicalisation.

\section{Critical viewpoints}

Although some criticism has been noted above, it would be remiss not to expand upon some of the key fault lines surrounding the concept. Horgan (2011) has voiced his concern with the "pre-occupation, if not obsession" on studying radicalisation, which he feels has 
had a detrimental impact on the wider understanding of terrorist behaviour. Schmid (2016) also raises a number of issues on the conceptual characterisation of radicalisation. Firstly, he feels that the lack of clarity and delineation between radicalism and radicalisation creates conceptual confusion (as raised by Awan et al. (2012) and discussed earlier). Schmid (2016) would prefer less emphasis on radicalisation and a greater academic focus on extremism, which as he points out is "regressive and authoritarian" (p. 28). Secondly, Schmid (2016) advocates for a broader analysis of radicalisation at the "meso-level of the radical milieu or the macro-level of society, state and international system", moving away from the focus on the vulnerable individual (p. 28). Kundnani (2012) argues that the study of radicalisation concentrates on the Muslim religion, and has become "limited to a much narrower question: why do some Muslims support an extremist interpretation of Islam that leads to violence?" (p. 5). Coolsaet (2015) also traces how radicalisation came to be the dominant topic in EU policy circles following the 2004 bombings in Madrid. In the search for simplicity, "radicalisation proved irresistible as a concept" (p. 6).

A recent debate between the French academics Olivier Roy and Gilles Kepel has generated significant academic interest in their relative positions on the causes of radicalisation. While both agree that marginalised young people are radicalised in France, they differ vehemently on how and in what context this process takes place (Manea, in Paul et al., 2017). The alternate perspectives they offer have implications for state responses further afield than France. According to Nossiter (2016), Roy places "greater emphasis on individual behaviour and psychology he considers strictly marginal to Islam" (p. 1). Kepel, meanwhile, believes that social and personal conditions are secondary to the influence of ultraconservative Salafist teachings such as The Global Islamic Resistance Call, written by Abu Musab al-Suri (Nossiter, 2016, p. 2). The disagreement between Roy and Kepel is relevant to both the researcher and the policymaker, and the extent to which one subscribes to either view will dictate whether efforts to counter radicalisation should focus on the individual and local factors (as per Roy), or on the Salafi strand of Islam which advocates violent jihad, which Kepel views as the dominant factor (Manea, in Paul et al., 2017). With regard to how the Irish state should respond, the models of Wiktorowicz (2004) and Precht (2007) would suggest that both Roy and Kepel are correct and that addressing background factors as well as extreme interpretations of Islam is required in order to adequately counter Islamist radicalisation. Having examined the concept and debate around radicalisation within the literature, it is appropriate to examine the practical state responses to radicalisation in Ireland and the chosen comparators, the UK and Denmark.

\section{State responses to radicalisation}

Since the turn of the century, many European countries have enacted comprehensive strategies to de-radicalise or disengage committed militants and more widely, to prevent the radicalisation of new ones (European Commission, 2020). The UK has significant experience of dealing with terrorism domestically, historically stemming from Northern Ireland, but more recently facing a heightened threat from Islamist terrorism. Denmark has similarities to Ireland by virtue of its size, population, and a relatively recent history of inward migration (Statistics Denmark, 2020). There are also societal and political similarities to Ireland.

The approaches adopted by the UK and Denmark have differed, though both are guided by the goal of addressing the social context, ideological issues and human factors which have been identified in the models of radicalisation examined earlier. Whereas Ragazzi (2017, p. 169) posits that the UK's Prevent model reflects a "securitisation of social 
policy", the approach in Denmark has been labelled by Johansen (2019) as the "welfarization of security" (p. 2). These differing approaches reflect a pattern which will merit further exploration in Part Three of this study, since they go to the heart of what will be the priorities within the respective national strategies. As such, for both historical and contemporary reasons, the policies of the UK and Denmark provide valid comparisons from which to evaluate the Irish State's approach to the issue.

\section{The United Kingdom}

The UK's 2018 Strategy for Countering Terrorism, CONTEST, seeks to prevent terrorism through a risk-reduction framework with four strands: Prevent, Pursue, Protect, Prepare, which are illustrated in Figure 2.4. below (UK Government, 2018, p. 26).

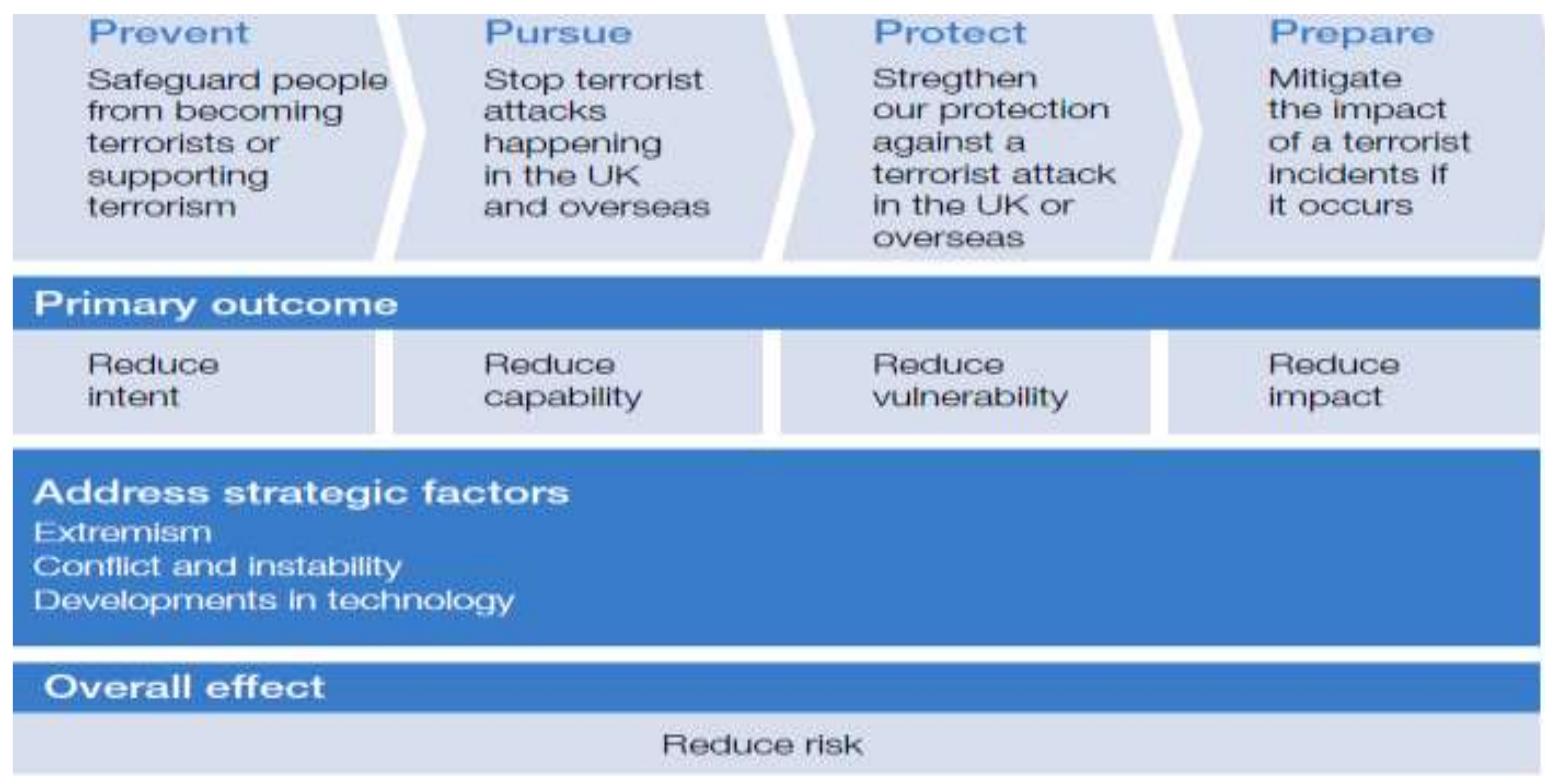

Figure 2.4. CONTEST's Risk Reduction Model (UK Government, 2018).

Substantial emphasis within Prevent is placed on identifying those at risk of radicalisation, which is defined as "the process by which a person comes to support terrorism and forms of extremism leading to terrorism" (UK Government, 2011, p. 108). Prevent sets out to work with key sectors and institutions to reduce the risk of radicalisation, safeguarding those at risk and responding to the ideology of terrorism (UK Government, 2011, p. 7). There is a clear legal framework to facilitate the work of Prevent; for example, local authorities are bound, under the Counter-Terrorism and Security Act (2015), to ensure that frontline staff are trained to recognise "individuals who are at risk of being drawn into terrorism" (UK Government, 2019, p. 7). Where necessary, individuals should be referred for supports such as "mentoring, counselling or theological support" under a programme called Channel (UK Government, 2011, p. 107). In extreme cases, those suspected of involvement in terrorism are to be referred to the police. The Prevent delivery model, depicted as Figure 2.5. below, shows the proactive approach to respond to the transmission of terrorist ideology, and an intervention-based approach to individuals assessed to be at risk of radicalisation. 


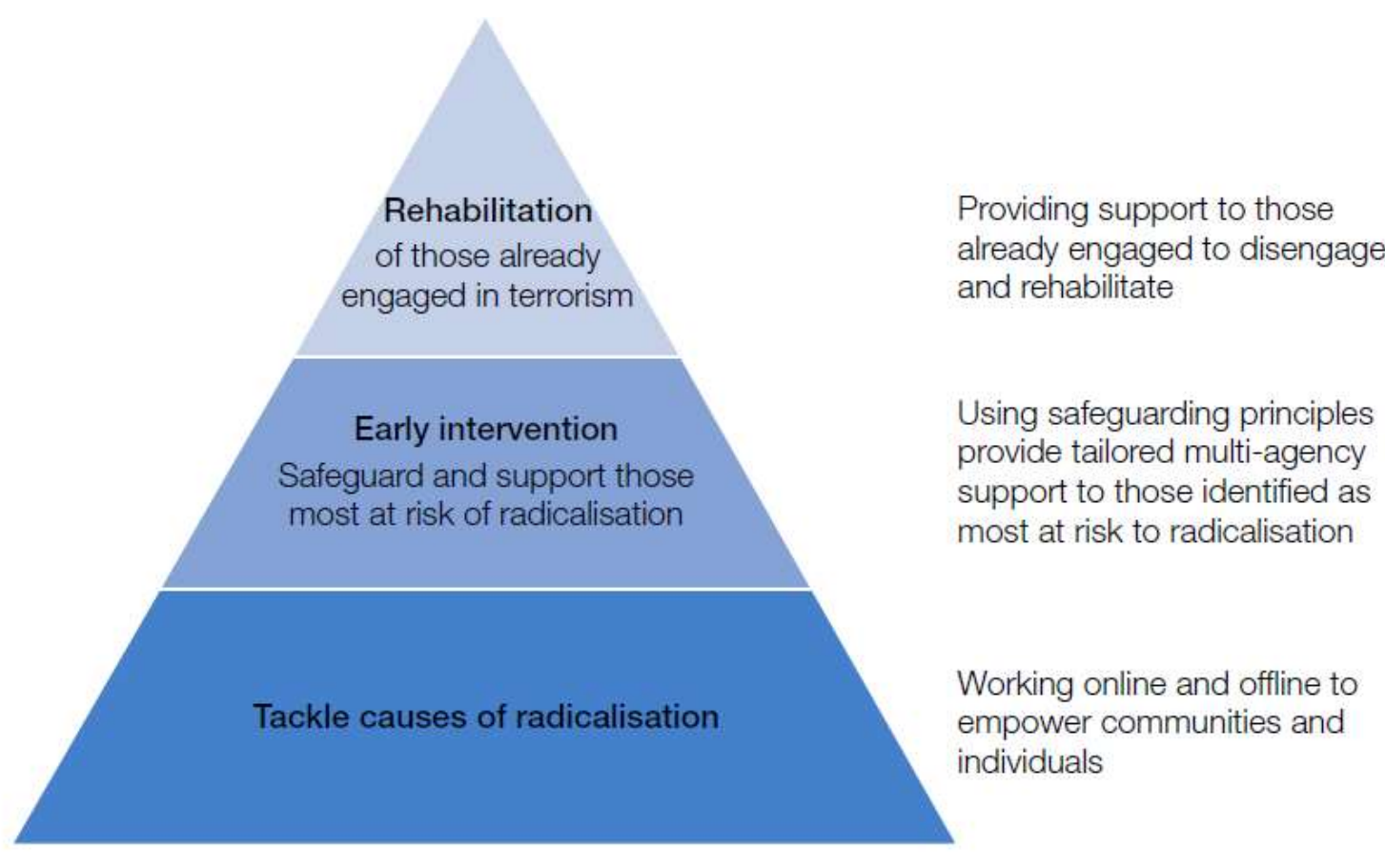

Figure 2.5. The Prevent delivery model (UK Government, 2018).

The effectiveness of the Prevent model has been widely debated, at various levels. On the macro-level, critics say that by its nature, it amounts to the securitisation of social policy, whereby a narrow group of professional individuals has too great a say over the maintenance of social order (Ragazzi, 2017). According to Taylor (2018), this contributes to alienation by labelling the entire Muslim community as "suspect" (p.1) and dividing the community into "risky" and "trusted"' categories (p. 2).

In addition to criticism of the focus of Prevent, others have taken issue with the definition underpinning the strategy. O'Donnell (2016) criticises Prevent's definition of radicalisation which, she argues, appears to suggest an observable, linear path "from an encounter with ideas to acts of violence" (p. 55). She also takes issue with the use of indicators to identify those at risk of radicalisation, which are so vague as to potentially cover a large proportion of the population (O'Donnell, 2016).

\section{Denmark}

The Danish government has published a National Action Plan named Preventing and Countering Extremism and Radicalisation, which defines radicalisation as "a short- or longterm process where persons subscribe to extremist views or legitimise their actions on the basis of extremist ideologies" (Government of Denmark, 2016, p. 7). The Action Plan (Government of Denmark, 2016) outlines how the Danish approach to countering radicalisation seeks to prevent terrorism, but also recognises that extreme views can impact societal cohesion by undermining values such as freedom and democracy. What is striking about the Danish approach is the breadth of inter-agency cooperation involved (including the police, the Danish security and intelligence agency, immigration and integration services, social services and education institutions), and the levels at which it operates, from state cascading down to municipal (Vidino, 2013; Government of Denmark, 2016). The dominant theme within the Danish approach is the emphasis on encouraging the individual to identify with the Danish state and to reject extremism (Hardy, 2018). A 
combination of general preventive measures and risk-assessed interventions are utilised (Butt and Tuck, 2014). Figure 2.6., below, illustrates the framework for interventions within the Danish approach, based on the assessment of an individuals' risk of radicalisation (Government of Denmark, 2016).

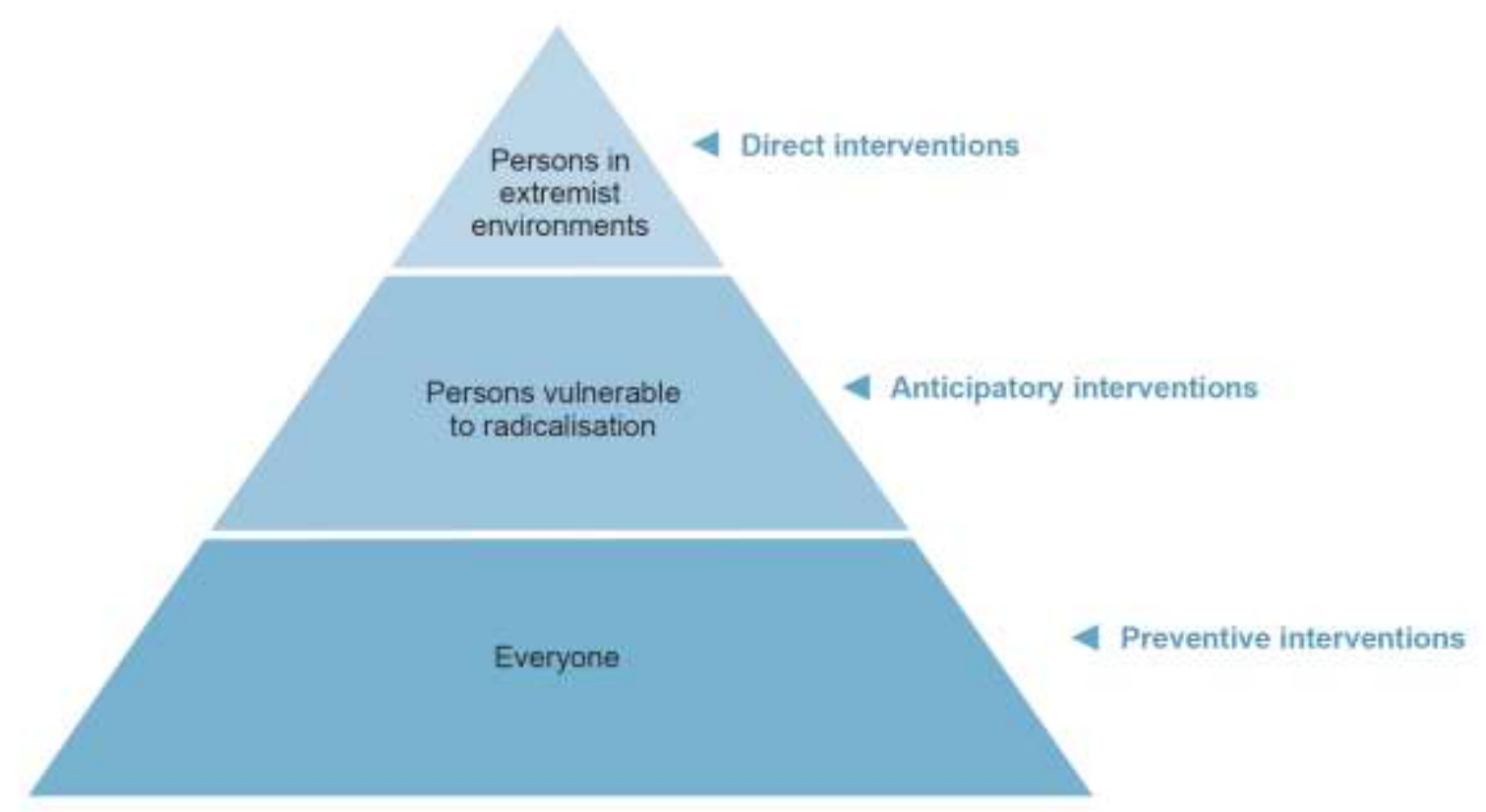

Figure 2.6. The Danish 'Prevention Pyramid’ (Government of Denmark, 2016, p. 16).

The base level of the pyramid seeks to reach all members of society, but especially the young, to engender trust and faith in citizenship and democratic values from a young age (Johansen, 2019). At the second level, those displaying evidence of risk of radicalisation are assessed at the local level and may be the subject of interventions if necessary (Vidino, 2013). The upper level of the pyramid is directed at those who are suspected to be most at risk and may display the potential to commit crime. Vidino (2013) observes how these direct interventions are mostly led by the police. The efforts to distance such interventions, where possible, from the perception of punishment (unless it relates to the potential commission of a crime) engenders trust within the Muslim community which is vital to ensuring continued support for counter-radicalisation approaches (Vidino, 2013). This mitigates the risk of alienation, which in itself has been identified within the literature as a potential factor in radicalisation (Kühle and Lindekilde, 2012).

In Denmark, social integration and "active citizenship" are seen as key issues in preventing radicalisation, supported by initiatives to provide education and employment opportunities for those assessed to be at risk of radicalisation (Butt and Tuck, 2014; Government of Denmark, 2016, p. 6). The emphasis on social integration reflects the country's experience with attempts to integrate communities of North African and Middle Eastern migrants from the 1990s onwards (ICSR, 2012). By prioritising integration into Danish society, it is hoped to prevent the development of "parallel societies" and thus ensure societal cohesion (Government of Denmark, 2016). The research conducted by Kühle and Lindekilde (2012) on young Muslims perceptions of counter-radicalisation practice in Denmark highlights the difficulty in delineating exactly what types of views can 
be tolerated and what is considered to be extremist, a difficulty which has arisen in the UK also (Kühle and Lindekilde, 2012; Taylor, 2018).

\section{Ireland}

Government Ministers have underlined how strongly Ireland supports international efforts to counter the threat posed by groups such as IS (DFAT, 2015). Although a robust legal framework exists to investigate and prosecute terrorist offences, the state's approach to national security has been characterised as reactive and discreet, and not as mature in comparison to other European countries (Mulqueen, 2009). This is exemplified by the lack of national counterterrorism or counter-radicalisation strategies. It is also noteworthy that there is a paucity of academic literature specific to the Irish experience of radicalisation.

Although the term 'radicalisation' appears in several government publications and websites, it is not clear that a standard definition is in use. This will be the subject of analysis in Part Three. Based on an initial examination of government publications, the state's guiding principles in responding to the issue of radicalisation acknowledge the complexity of the issue, the need to protect the security of the state, and the need for a rights-based approach (DOJ, 2019b). The primary actors appear to be an emphasis on migrant integration (DOJ, 2017), and policing actions by An Garda Síochána (DOJ, 2017).

Mulqueen (2009) has identified the key role played by immigration control and integration initiatives as part of Ireland's attempts to minimise the risk of radicalisation. The Migrant Integration Strategy (DOJ, 2017) speaks of the need to move beyond the newly arrived and consider existing residents who continue to struggle to integrate. The strategy also identifies radicalisation as a risk; the challenge it states, "will be to reach out to young people at risk of radicalisation to encourage them to participate constructively in Irish society" (DOJ, 2017, p. 8). This indicates that the Irish State hopes to prevent the emergence of the type of conditions for radicalisation identified by Precht (2007). A weakness within this approach is that it appears to fail to take account of either long-term residents of Ireland or Irish born converts to Islam. This is a concern given that there are records of at least two Irish citizens fighting for IS, in addition to the well-known case of self-confessed IS-supporter Lisa Smith (McMahon, 2016; Keena, 2019; Beresford, 2019).

There has been no official acknowledgement from the Irish government of the number of Irish citizens who have travelled to the conflict in Syria and Iraq, although the then Minister for Justice and Equality, Frances Fitzgerald TD acknowledged that " 25 to 30 individuals of Irish origin have travelled to conflict areas in North Africa and the Middle East since ... December 2010" (Oireachtas na hÉireann, 2015). Shaykh Umar al-Qadri, chair of the Irish Muslim Peace and Integration Council, stated his belief that there are "about 100 sympathisers with more extreme Islam in Dublin's Muslim community" as he called for the State to adopt a more proactive approach against those who support IS (McGarry, 2019). His comments reflect the notion that there is a spectrum of Islamic beliefs prevalent among the Muslim population, including extremist interpretations of Islam. The nature of the Muslim community, and its perceived homogeneity, will be examined in Part Three.

In tandem with social inclusion initiatives is the existing criminal justice model led by An Garda Síochána; with community policing to build trust and prevent crime (An Garda Síochána, 2019b), and the investigation of suspected terrorist offences by specialist officers (An Garda Síochána, 2019a). Ireland has decades of experience in dealing with terrorism, perpetrated by Republican and Loyalist paramilitary groups. The 2019 launch of 
an Action Plan for the Joint Management of Offenders (2019-2021), to introduce a system for An Garda Síochána, the Irish Prison Service and the Probation Service to share information more effectively on offenders at risk of radicalisation is perhaps a sign of a more proactive approach, reflective of our European neighbours (DOJ, 2019a).

\section{Conclusion}

This review has considered the relevant literature on the subject of radicalisation, and examined the approaches adopted by Ireland, the UK and Denmark in response. A number of key themes have emerged which frame further analysis in Part Three. Firstly, the challenge of defining radicalisation in the Irish context, as a foundation upon which to build national policy and strategies. It is clear from the literature that there are enduring issues around the conceptualisation of radicalisation. While there appears to be consensus around the notion that radicalisation is a process which can lead to the development of extremist views and possibly to terrorism, the lack of agreement on what constitutes radicalisation and how it manifests itself poses a difficulty. This uncertainty around the nature of radicalisation is especially relevant to Ireland, as no official government definition of radicalisation is apparent from the documents examined in this research.

Following this, three interconnected issues arise which should form the core of a state response: how to approach the individual at risk of radicalisation, how to confront the ideology of extremism, and how to address the environment in which the individual and ideology interact. The UK and Denmark have differing methods for leveraging the general environment to minimise the potential for radicalisation. In the UK, the perception of Prevent is that it is police-led, with social services secondary (Ragazzi, 2017). In Denmark, by contrast, a 'whole of society' approach is used, with social services in the lead (Johansen, 2019). The references to radicalisation in Irish government documents indicate that while the Irish state is aware of the challenges around the issue of radicalisation, it appears to be responding in a sector-specific fashion (DOJ, 2017; Gallagher, 2019), and has not yet addressed the challenge of formulating a coherent strategy, as has been implemented in other European countries. The examination of the Wiktorowicz and Precht models demonstrates that it is possible, based on these stages and factors, to identify indicators which could signify an individual's susceptibility to radicalisation. They also show that social group dynamics, individual identity, and relative deprivation are key issues which have been observed to facilitate and contribute to radicalisation. Within the counterradicalisation strategies examined, this is seen by the concentration on responding to terrorist ideologies, identifying individuals at risk of radicalisation, and ensuring that environmental factors do not encourage radicalisation. A framework for the analysis of data to be collected through documentary analysis and semi-structured interviews will be expanded upon in Part Two.

\section{PART TWO. Research Methodology}

Taking into account the emphasis upon the personal process of radicalisation, and the states response, qualitative research methods were the most appropriate research methods in preparing this paper. Within the qualitative approaches outlined by Creswell and Poth (2018), a phenomenological approach was chosen.

\section{Sources and data collection}

In the literature review, it was identified that radicalisation is a deeply personal and individual process, and that strategies to prevent it are fraught with difficulties. Therefore, within the phenomenological approach, the collection of data from areas where the most 
context could be gleaned was prioritised (Gray, 2004). Documentary analysis of the UK and Danish national strategies to prevent radicalisation was conducted, in addition to semistructured interviews with a carefully chosen sample group.

\section{Documentary analysis}

The commencement of the data collection process was documentary analysis. A number of Irish government strategies and reports were examined, including the White Paper on Defence Update (DOD, 2019), Annual Reports of An Garda Síochána (AGS, 2015; AGS, 2016; AGS, 2017; AGS, 2018), the Action Plan for the Joint Management of Offenders (DOJ, 2019a), the Migrant Integration strategy (DOJ, 2017), and the Report of the Commission on the Future of Policing (CFPI, 2018). The UK Strategy for Countering Terrorism (CONTEST) (UK Government, 2018), and the Prevent Strategy (UK Government, 2011), and Denmark's National Action Plan Preventing and Countering Extremism and Radicalisation was analysed (Government of Denmark, 2016) were analysed for themes related to defining radicalisation, the individual, the ideology and the environment, in accordance with the data analysis framework developed from Part One.

\section{Semi-Structured Interviews}

Following the documentary analysis, semi-structured interviews were conducted to address the knowledge gaps identified in Part One. Pre-determined, open-ended questions were used, and interviews were sequenced so as to allow the focus and nature of each interview to evolve from the previous one. All interviews were recorded, transcribed, and then analysed in accordance with the data analysis framework outlined in Figure 3.1 below. The rationale behind the composition of the sample group, which was essential to the integrity and validity of the research, is outlined in the section below.

\section{Sampling}

The sampling strategy used was purposeful convenience sampling. This sampling method is ideally suited to this research given the sensitive and specialist nature of the research. Convenience sampling has both advantages and disadvantages, including the risk of excessive bias or influence being exerted by the sample group (Frey, 2018, p. 403). To mitigate against excessive convenience at the expense of quality, a great deal of consideration was given to the composition of the sample group, to ensure that it included a balance of practical, academic, and social expertise. Careful consideration of the questions asked during interviews, as well as a reflective approach during data analysis complemented this.

Interviewees included a former DF Director of Intelligence, and a prominent Islamic theologian, both of whom requested that their data be anonymised, along with Mr. Declan Power (journalist and security analyst), and Dr. Maja Halilovic-Pastuovic (Senior Research Fellow at the School of Religion, Trinity College Dublin). Interviewees were chosen so as to allow for the collection of a diverse range of views from which to gather perspectives from the fields of security, the media, academia, politics, and Islam.

\section{Data analysis}

With the semi-structured interviews completing the data collection process, inductive reasoning was used to analyse and link the findings to the themes identified in the literature review and thus ascertain the aspects most relevant to radicalisation in the Irish context. The data analysis framework utilised, which identified the need to define radicalisation, and focussed on the themes of the individual, the ideology and the environment, is depicted in Figure 3.1. below. 


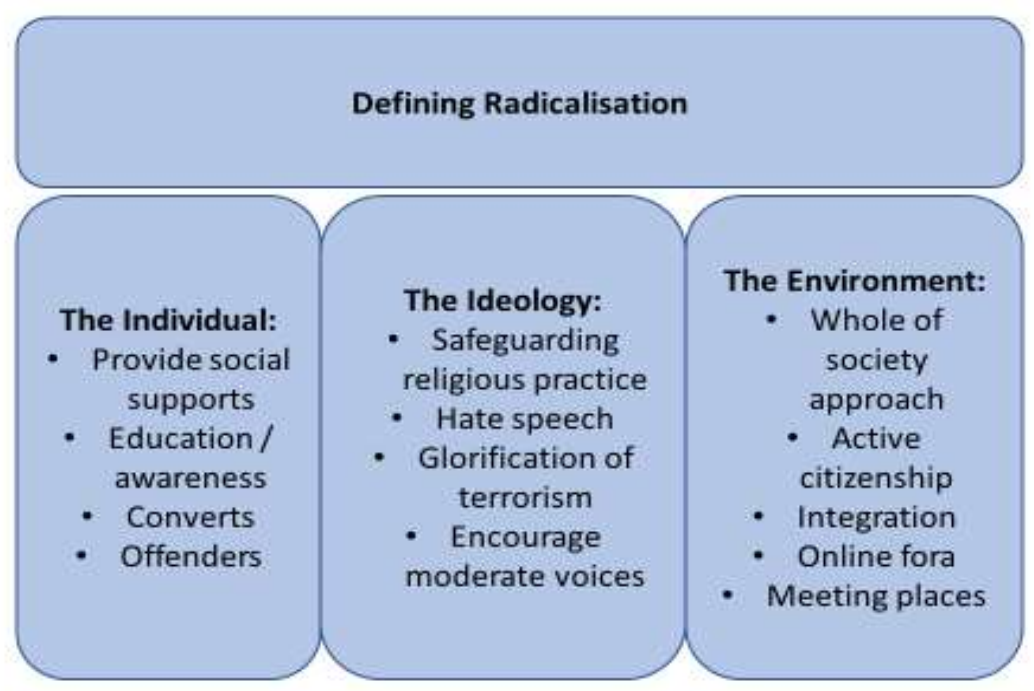

Figure 3.1. Data analysis framework.

\section{PART THREE. Analysis and Research Findings}

The analysis and findings based on the data collected through documentary analysis and semi-structured interviews are presented here. The review of the literature on radicalisation in Part One highlighted a number of key areas warranting further research and analysis, including the challenge of conceptualising radicalisation, which would be essential in providing guidance for any Irish counter-radicalisation efforts. Three additional themes emerged from the review as being relevant to assessing how the state should respond to the radicalisation of Irish citizens by Islamist groups: the individual, the ideology, and the environment in which the individual and ideology interact. Analysis is structured in accordance with the framework depicted in Part One, with findings from both documentary analysis and semi-structured interviews interspersed thematically. Sub-themes have been identified using the definition of King and Horrocks (2010).

The first finding is an overarching perception among interviewees that Ireland maintains a reactive approach to security. Examination of the theme of the individual reveals differing opinions on whether counter-radicalisation efforts should be directed at the individual or the society, though the fact that Ireland appears to have avoided some of the background factors which Precht (2007) and Wiktorowicz (2004) have identified as facilitating radicalisation is highlighted. The importance of influence during the radicalisation process emerges under the theme of ideology, an issue also identified in the literature. Finally, the theme of the environment has emerged as a key intersection for all of the findings, pointing to the challenge of preventing the development of closed-off communities which could facilitate radicalisation, while also respecting individual and community rights. The final finding, the identified need for improved government communications and coordination, has echoes of the first finding, Ireland's prevalent attitude to security, which is presented now.

\section{Ireland's attitude to security}


Interviewee A, a former DF Director of Intelligence, labels Ireland's efforts to counter radicalisation as "ad hoc, at best" (2020). He points to what he feels is a national pattern of complacency and reactivity:

as a state, at governmental level, at policy level, at the infrastructure level, we have a very naïve approach to state security and addressing security issues in a proactive manner. I believe that the political view is to let sleeping dogs lie. If it doesn't threaten us, why would I risk doing something that might put our heads above the parapet and cause us harm? (Interviewee A, 2020).

Power, a journalist and security analyst, also perceives a reactive approach to security matters in this country, and expresses his worry that Ireland is viewed as a "weak link in the chain, within Western Europe" (2020). He underlines the importance of politicians' perception of an issue as a precipitant to action: "policymakers have to see an issue as important, and policymakers, generally, see things as important when it impacts on votes, on jobs, or the economy" (Power, 2020). The issue of competition for the allocation of resources within government arose frequently. Referring to the lack of national strategy on radicalisation, Interviewee A states: "for a strategy to be introduced, it would require more resources and coordination which would divert resources, personnel and finances away from other areas, and that is a key reason why the government has never grasped the nettle" (2020). Halilovic-Pastuovic, a Senior Research Fellow at the School of Religion, Trinity College Dublin, highlights the difficulty in proving the effectivity of counter-radicalisation initiatives: "the problem with counter-radicalisation measures are that they are not evaluative ... how can we prove with certain preventive measures that we actually prevented the radicalisation?" (2020). The responses of the interviewees concur on the prevailing approach to security in this country being a reactive one, whilst also displaying an unwillingness to prioritise the expenditure of resources for the provision of security when the results are difficult to quantify. The responses of interviewees regarding the reactive nature of the Irish state's response to radicalisation is also relevant to other themes identified, most notably the duty of care to the individual, which is examined below.

\section{Defining radicalisation}

The importance of defining radicalisation as a basis for any future counter radicalisation strategy is noted by Interviewee A; "we should have a strategy ... but you'll need a definition as a start point, to focus efforts, something to provide clarity" (2020). Several other subthemes relating to the issue of definition emerged during the semi-structured interviews, and these are examined hereafter, beginning with the situation in Ireland.

\section{How does Ireland define radicalisation?}

Ireland does not currently have a specific counter radicalisation strategy. As outlined in Part Two, relevant Irish government documents and websites were analysed to ascertain what, if any, definition of radicalisation is in use by government. Radicalisation is identified as a risk or threat to be managed, but no definition of radicalisation was proffered. The lack of an explicitly stated definition misses the opportunity to provide clarity as to what the state understands the term to mean, what it includes or excludes, or indeed whether all organs of the state are operating from the same base of understanding on the issue. For example, when the Garda Síochána Annual Report for 2018 states that the organisation is "taking steps to prevent extremism and radicalisation" (AGS, 2018), with no further information, 
the reader is left uninformed as to the depth or extent of the measures being taken. The absence of a definition of radicalisation in published documents, or at the very least the failure to acknowledge that such a definition exists, is a strong indication that no standardised cross-government definition is in use. The apparent absence of such a fundamental building block is indicative of an under-developed approach to the issue from state authorities generally. The importance of a unified, whole-of-government response to radicalisation will be discussed later.

To provide context from international sources, the counter terrorism and counter radicalisation strategies of the UK and Denmark were analysed to ascertain how each country approaches the issue of defining radicalisation. It is not intended to analyse the composition of any definitions in detail, but rather to ascertain whether a national definition is used, and if so, to identify what significance the totality of the definition brings to that national strategy.

The United Kingdom - preventing people from supporting terrorism

Within the overarching CONTEST framework, the Prevent Strategy goes to considerable lengths to provide clarity on the use of specific terms, including a detailed glossary of definitions, with radicalisation defined as "the process by which a person comes to support terrorism and forms of extremism leading to terrorism" (UK Government, 2011, p. 108). The Prevent approach, and definition of radicalisation, have proved divisive, with critics arguing that it is counter-productive and alienates Muslims (Taylor, 2018), but the definition does clearly provide a guiding ethos to the Strategy, supporting its goal "to stop people becoming terrorists or supporting terrorism" (UK Government, 2011, p. 6). Prevent thereby supports the aim of the superordinate CONTEST strategy, which aims to reduce the risk of terrorism (UK Government, 2018, p. 25). Viewed in their totality, the clarity and use of definitions provides a conceptual and practical coherence to the strategies.

\section{Denmark - promoting 'Danish values' and 'active citizenship'}

The Danish Action Plan defines extremism and radicalisation, with the two definitions clearly linked. Radicalisation is defined as "a short- or long-term process where persons subscribe to extremist views or legitimise their actions on the basis of extremist ideologies" (Government of Denmark, 2016, p. 7). The reader can visualise a spectrum where radicalisation leads on to more extreme views, with extremism identified as the conduct or support for violence or illegal acts (Government of Denmark, 2016, p. 7). In making this identification, the Danish approach is reminiscent of what Neumann (2013) describes as extremist beliefs ("cognitive radicalisation") and extremist behaviour ("behavioural radicalisation") (p. 873). The aim of the Danish Action Plan: "not merely to ward off terrorism - it also has wider implications for society" (Government of Denmark, 2016, p. 6), clearly contrasts with the UK's Prevent Strategy (2011), with its focus on the individual. The Danish approach thus seeks to operate at the macro-level, to strengthen the society by protecting Danish values, and encouraging active citizenship by all (Government of Denmark, 2016, p. 6).

\section{Radicalisation: A complex, individual, cognitive process}

The complex nature of the concept and the difficulty of defining radicalisation can be clearly seen in the contributions of all interviewees. Many of their contributions cut across the themes which will be covered later. Accordingly, a summary is offered here, and specific issues are expanded upon under the respective themes. Three elements were prominent across the responses of all interviewees. Firstly, that radicalisation is a process. Secondly, that this process is unique to each individual, and is impacted by many factors, including 
but not limited to the person's background, social status, economic situation, and identity. Thirdly, that radicalisation involves the development of extremist beliefs that can go so far as to legitimise the use of violence. Whilst Interviewee A (2020) characterised radicalisation as "the process of developing extremist beliefs, emotions, and behaviours", both they and Power acknowledge that radicalisation does not necessarily lead to an individual becoming a terrorist, indicating that they subscribe to Neumann's (2013) view of a distinction between cognitive and behavioural radicalisation. Halilovic-Pastuovic is adamant that a definition of radicalisation "has to be connected with violent action" as distinct from merely radical views (2020). The data collected from participants underscores the divergent opinions on where the state should identify the definitional difference between radicalisation and extremism, and strongly suggests the need for a consultative process prior to a national definition being promulgated.

\section{A definition becoming a straitjacket?}

Halilovic-Pastuovic cautions on the dangers of creating an inflexible definition which ties the hands of law enforcement practitioners: "when a definition is left loose in the right hands, then it's an approach that I would advocate. But if it's left loose in the wrong hands, then it could be harmful, and that's a tightrope to walk" (2020). She foresees problems with an inflexible approach, because "when we create categories, we create problems because we always tend to come to these grey areas" (Halilovic-Pastuovic, 2020). Navigating these grey areas requires an in-depth understanding of the complexity of radicalisation among law enforcement and associated government agencies, which she does not believe currently exists in this country. This is a perception which echoes, from the practitioner level, to the strategic weaknesses identified by Interviewee $A$ and Power above, in relation to the collective attitude to security.

\section{Not just a Muslim issue}

In addition to their opinions on the construct of a definition, all interviewees were clear that radicalisation is not just an issue in the Islamist context, and can "be applied to the indoctrination of recruits for the far-right, or even militant socialists, or other political groupings" (Interviewee A, 2020). The views of interviewees underline the futility of viewing radicalisation as solely an issue for the Muslim community; and how any attempt to counter Islamist radicalisation must form part of a wider initiative to address the issue across the spectrum of political viewpoints.

\section{Summary}

The apparent lack of an Irish definition of radicalisation highlights an important structural gap in the Irish approach, and interviewee's divergent opinions on the construct of a definition reinforce the need for widespread consultation in order to arrive at a workable definition.

\section{Theme One: The Individual}

The data collected during documentary analysis and semi-structured interviews clearly illustrates the belief that radicalisation is a process which takes place within an individual but can be affected by external considerations and influences. The extent to which the state seeks to prioritise the setting of barriers to radicalisation upon the individual or on strengthening society as a defence, introduces an important nexus in the debate. The specific thematic areas relating to the treatment of the individual which arose during the data collection process, including risks identified, are outlined in the proceeding section. 
The models of radicalisation put forward by Wiktorowicz (2004) and Precht (2007) examined in Part One identify indicators which relate primarily to the individual and could be used to identify those most at risk of radicalisation. The use of indicators is an important part of the prioritisation of "vulnerable individuals" for "safeguarding" under the Prevent Strategy (UK Government, 2011, p. 97). In fact, "protecting vulnerable people" is one of the three objectives of Prevent (UK Government, 2011, p. 55). This underlines how Prevent (2011) is focussed on the individual, at the micro-level. On the contrary, in the Danish Action Plan (2016) the emphasis is identified as strengthening society at the macro-level, through the strength of many. There are repeated references to collective areas such as "communities" or "residential areas" as being vulnerable, there are few references to vulnerable individuals. The transition from an emphasis on the individual and a shift to the meso- or macro-levels of society is a concept advocated for by Schmid (2016). This resonates with the view of Power on the need for "communities being literate and sensitised to spot the seeds of extremism within their community" (2020). Power identifies a role for members of the community to act as trusted interlocutors, and "open the right door to the right person" when someone is at risk of radicalisation (2020). Power sees benefits in "communities being literate and sensitised, to spot the seeds of extremism", and thus enable them to identify people at risk of radicalisation and then "open the right door to the right person, and act" (2020). The benefits of a broad awareness of the indicators of radicalisation, is commonly seen across the contributions of all participants.

\section{Background issues}

During the semi-structured interviews, participants spoke of the background issues which can make an individual vulnerable to radicalisation. Power believes that measures to prevent radicalisation should "give the State and the society the tools to protect themselves and fundamentally, the people, the communities at risk" (2020). Interviewee $B$, a prominent Islamic theologian, raises integration and identity issues which could make someone more likely to be radicalised, for example "where the person hasn't really been embraced by society ... because of his religion, identity, immigrant background, that person who has been bullied at school" (2020). Interviewee B (2020) is also clear in his view that socio-economic status is no barrier to radicalisation. It is noteworthy that although both Wiktorowicz (2004) and Precht (2007) refer to relative deprivation and injustice as being factors which facilitated radicalisation, particularly in the early stages of the process, these were not identified as significant to the Irish situation by any interviewees. In Denmark, the state seeks to remove the emphasis from the individual and "break the cycle of negative social inheritance" and thus ameliorate the risk of radicalisation by providing individuals with education opportunities, social supports and housing, which fits with the overarching goal of strengthening the society as a whole (Government of Denmark, 2016, p. 22).

\section{Risks}

Some risks associated with the treatment of the individual were identified during data collection. Interviewee B is clear in his belief that any Irish responses to radicalisation should be proportionate: "we don't want to become a police state, where every action of the person is being monitored" (2020), given the danger of alienation. The Prevent Strategy itself acknowledges that this mistake had been made in earlier iterations of the strategy by suggesting that Muslims were more vulnerable to radicalisation than others (UK Government, 2011, p. 7). Based on his own experience working on countering violent extremism in Africa, Power outlines how state actions can prove counterproductive if they are disproportionate, poorly planned, or enacted: 
there was a tendency that anybody with any kind of radical opinion was labelled as a terrorist, and if they weren't leaning towards extremism, or violent extremism, at the start of that process, they certainly were at the end of it because the state had pushed them in that direction (Power, 2020).

\section{Theme Summary}

A number of significant factors arise from the contributions of interviewees on the theme of the individual. Firstly, there appears to be no consensus on the extent to which counterradicalisation efforts should be oriented towards at the societal macro-level or the individual micro-level. Secondly, contributions suggest that Ireland enjoys an advantage owing to the absence of some of the background factors such as deprivation and injustice, identified as indicators of radicalisation by Wiktorowicz (2004) and Precht (2007). A number of risks with regard to the treatment of the individual have however been raised, reflecting the level of caution among contributors, and illustrating the complexity of the challenge.

\section{Theme Two: The Ideology}

Data collected during semi-structured interviews illustrates that there is widespread agreement that any efforts to counter Islamist radicalisation in Ireland must be carefully balanced to avoid stigmatising the Muslim community. Legitimate religious beliefs should be distinguished from the ideology which uses religion to justify extremism and terrorism. However, the importance of influence during the radicalisation process has also been identified and a number of key sub-themes did emerge.

\section{Influence}

The issue of influence, either face-to-face, or remote (online) during an individual's process of radicalisation was a recurring theme during semi-structured interviews. Interviewee $A$ (2020) spoke of the person being "led" into the process, while Power spoke of how ideological influence can precipitate the development of extremist beliefs: "in the hands of a good ideologue, it leads them down the route to considering the legitimacy of violent extremism" (2020). With reference to Islamist radicalisation, Interviewee B underlined how Ireland, by virtue of geographic proximity to the UK, has seen the spread of extremist views, for example by the extremist preacher Anjem Choudhry and "other radicals that agreed with Boko Haram, agreed with ISIS, agreed with their mentality, they had easy access to travel to Ireland" (2020). He suggests that their preaching contributed to the radicalisation of Irish citizens, "and yet ... the government, I think, they lacked the legislation to act" (Interviewee B, 2020). Interviewee B also believes that the Muslim community should have done more to prevent the spread of radical views, even if this was improved gradually, over time: "slowly, they decided to take steps, some preventive measures, they were isolated by the community" (2020). The comments by Halilovic-Pastuovic regarding the relevance of influence during an individual's search for belonging, are also relevant, and these are discussed below.

\section{Religious Preaching}

On the issue of religious guidance and influence in the positive sense, it was commonly agreed that religious leaders should be consulted in the formulation of measures to address radicalisation. Although the UK funds initiatives to train imams, recognising "the key role of Imams in reaching young Muslims" (UK Government, 2011, p. 52), and Denmark has introduced "a series of initiatives targeting religious representatives who seek to 
undermine Danish laws and values" (Government of Denmark, 2016, p. 25), none of the interviewees suggested any form of regulation of religious representatives.

\section{Prison pastoral care}

Interviewee $B$ raised the duty of pastoral care for Muslim inmates in Irish prisons to provide a buffer against radicalisation, given that prisons have seen issues with radicalisation in other countries. Prison-specific measures figure prominently in both the UK (UK Government, 2011) and Denmark (Government of Denmark, 2016). Interviewee B believes that a failure to provide for Islamic pastoral support within Irish prisons feeds "this notion of us versus them" (2020). Given the apparent lack of Islamist radicalisation within Irish prisons heretofore, it offers an opportunity for the State to demonstrate a proactive response and thereby ensure that the issue is less likely to develop in prisons here.

\section{Religious seeking and the cognitive opening}

In their models of radicalisation, Wiktorowicz (2004) speaks of the individual's religious seeking as an identifiable stage, while Precht (2007) speaks of conversion and identification with Islam. These are particularly associated with those who either undergo a hardening of their Islamic views or convert to Islam. Interviewee B feels that the Muslim religious leader has a duty of care to that individual to look after their welfare:

me, for example, as a Muslim leader. I have a duty of care. When people come to me, they want to change religion. I also need to ... understand that. Why is the person really wanting to change religion? You're not just saying, oh, I'm happy that you want to become Muslim, but actually think, and try to assist that person further (2020).

In that regard, he is an advocate of training to recognise individuals who may be vulnerable and a structure to provide advice and assistance.

\section{Belonging}

Halilovic-Pastuovic (2020) suggests that a person who, by virtue of a crisis in their life, may be searching for a new worldview or belief system (which Wiktorowicz (2004) labels as the cognitive opening), can be equally vulnerable to different extremist ideologies. She posits:

it's just who gets them first. It's not that these people ... that they have read the Qur'an, for example, or the right-wings know everything there is to know about the Great Replacement Theory, the right people just get them. The recruiters are good at this (Halilovic-Pastuovic, 2020).

Interviewee B concurs, identifying the greatest lure for people in that situation as a "sense of belonging" (2020). While Halilovic-Pastuovic (2020) is wary of the use of indicators in identifying those at risk of radicalisation, "not enough evaluation has been done that this is actually possible", she does agree that "it could possibly work well, if you had a really well-developed social protection infrastructure" (2020). She is, however, sceptical that such well-developed infrastructure exists in this country at present. To foster a sense of belonging among young immigrants in Denmark, the integration agency SIRI ${ }^{1}$ encourages

${ }^{1}$ SIRI is the Danish Agency for International Recruitment and Integration (Government of Denmark, 2016, p. 14. 
debate on topics which could straddle the boundary between Danish values and Islam, for example family relations, self-expression, social control and honour-related conflicts, which are "significant to their development, independence, and sense of belonging to communities in society" (Government of Denmark, 2016, p. 22). On the subject of values, Halilovic-Pastuovic strikes a cautious note with regard to Ireland: "I would be very wary of ... creating a counter-radicalisation strategy based on a glossary, so to speak, of common values. I don't think it would lead to solutions"; "if you want to separate Irish values from ethnicity and church, it would be very difficult" (2020). It is interesting to note that beyond "liberty, democracy, safety and the right to self-determination for the individual", the Danish Action Plan does not specify Danish values, but does specify the need to "fight those forces that promote violence, hatred and oppression with determination" (Government of Denmark, 2016, p. 3).

\section{Theme Summary}

Interviewees have highlighted the need for the state response to radicalisation to take account of the key role played by influence during the process, and echoing the models of Wiktorowicz (2004) and Precht (2007), some interviewees expressed support for measures to regulate the spread of hate speech and those glorifying violence. These are concepts that permeate into the measures taken to counter radicalisation within the environment, which is expanded upon below.

\section{Theme Three: The Environment}

In Precht's (2007) model, the environment surrounding the individual impacts across all four stages of the radicalisation process, but most acutely in the early stages, where it can provide key motivation. Background factors are equally present in Wiktorowicz' (2004) findings, but the closed-off nature of the al-Muhajiroun group and their ability to publicly preach radical ideas was identified as especially important to their radicalisation activities. Therefore, the approach to the environment within which the individual and ideology interact represents a pivotal pillar of counter-radicalisation measures. Interviewee B contends that by not challenging hate speech and by allowing extremist preachers to travel here and reach their audience, we "allow, and promote an atmosphere where the process of radicalisation can continue and can survive" (2020). In terms of how to craft an environment to prevent radicalisation, a number of sub-themes emerged, which are valuable in suggesting boundaries within which a national framework could be crafted. These are set out below.

\section{The protection of individual freedoms}

During semi-structured interviews, it was acknowledged by participants that monitoring or surveillance of those suspected of holding extremist views might be required, but with disagreement on the threshold for this, to "balance not being a police state and at the same time as its required, that you engage and you take action" as Interviewee B (2020) suggested. For example, Interviewee A felt that Gardaí should assess those "exhibiting signs of radicalisation" (2020). Halilovic-Pastuovic underlines the need for any police action to be proportionate and related to a terrorist act: "we should go, in Ireland, against surveillance, particularly surveillance of the Muslim population. Until the terrorist act is committed, we need to be careful how we act" (2020). Halilovic-Pastuovic stresses the need for "non-violent problem solving" and suggests "teaching the non-violent approach and the ability to dissent, the ability to protest within a democratic setting" (2020). All participants expressed opposition to any form of sustained surveillance of the Muslim 
community as part of counter-radicalisation measures, citing the potential risk of stigmatisation and alienation.

The perceived homogeneity of the Muslim Community in Ireland

While interviewees expressed support for religious leaders being consulted in the preparation of counter-radicalisation measures, Power raises an important point regarding the tendency "within official Ireland, within the media" to portray the Muslim community in Ireland as a homogenous unit, which he contends it is not (2020). Interviewee B's point that although "the Muslim community is a very small community ... it's not necessarily very close" (2020), reinforces the need to understand the specific Irish context during the formulation and enacting of measures to counter radicalisation.

\section{Integration}

Feelings of isolation, injustice and deprivation have been identified by Precht (2007) as potential precursors of radicalisation. Interviewee A notes that Ireland, unlike other European countries, has avoided the development of so-called immigrant ghettoes, which can "become breeding grounds for radicalisation, alienation and disaffection of young people" (2020). His contended that "it needs to be tackled at source ... policies to tackle the issue in a meaningful way, integration, schooling, jobs" (2020). The Migrant Integration Strategy does speak of reaching out to young people and encouraging them to participate constructively in Irish society (DOJ, 2017, p. 8). This echoes the Danish goal of integrating migrants into communities, from housing to education and social activities, which forms a key element of their efforts "to stem the negative influence of extremist groups in local communities" (Government of Denmark, 2016, p. 6). On the law enforcement side, Danish security forces are tasked to identify "virtual communities on social media and group communities like those existing in criminal groups, prisons, and Islamist groups which may be conducive to the radicalisation process" (Government of Denmark, 2016, p. 10). This is demonstrative of the comments from interviewees on the protection of individual rights, discussed above.

\section{Policing and Situational Awareness - today and for the future}

The importance of Gardaí establishing and maintaining good relationships with members of the Muslim community to build trust was a common theme during semi-structured interviews. The benefits of community policing were noted by Power: "they're the soft face of the policing instruments of the state and they've done a very good job" (2020). As Halilovic-Pastuovic points out: "Guards who dealt with cases would have been guards who were known to the community" (2020). This echoes the finding of Vidino (2013) relating to the Danish police approach to interventions under the 2016 Action Plan, as discussed in the literature review. However, Interviewee A raises the issue of the gap between community policing at the local level and counterterrorism policing, especially for "horizon scanning ... looking at threats from five to ten years out, to alert policymakers" (2020). This echoes back to his contribution on the provision of security in this country.

\section{Governmental Cooperation and Coordination}

Although participants had differing views on the conceptualisation of radicalisation and consequently also differed on the cognitive versus behavioural focus of counterradicalisation efforts, there was broad agreement that whatever form the State chooses to respond to radicalisation, it must be a whole of government approach. Halilovic-Pastuovic (2020) identifies what she perceives to be existing failings in communications across government departments. Power stresses the need for a whole-of-society approach to 
radicalisation, but is specific in his view on the need for a coordinated, cross-departmental approach within government:

to do this properly is not just a Garda role, you know, the Department of Social Protection, Department of Education, Department of Health, all of those and others need to be brought into this conversation with a view to building a concept that is relevant to our needs in this country (Power, 2020).

\section{Theme Summary}

The environment has emerged as the key intersection between other themes. Interviewees are clear that closed-off communities which could harbour the process of radicalisation must not be allowed to develop, but equally that individual and community rights must be protected. The need for improved communications, coordination and planning between state agencies was also highlighted.

\section{Conclusion}

The findings identified in the data collection process have been outlined the preceding sections. In some instances, the findings have confirmed, or expanded upon, existing knowledge, in others they have raised new issues which illuminate how the state should seek to respond to Islamist radicalisation. The key findings are outlined below:

- Ireland's approach to providing security, and for dealing with radicalisation, is not sufficiently proactive. The lack of complementary and coordinated national strategies to address national security, terrorism, and radicalisation place this country at odds with the approaches of most European Union (EU) countries. If not addressed, this will continue to result in a reactive approach to events.

- There appears to be no government definition of radicalisation, which would aid in serving as a foundation for further response mechanisms.

- Radicalisation is a complex, individual process, but can be precipitated or accelerated by external factors. Strong community cohesion and a rejection of extremist ideologies can work in preventing radicalisation, and appropriate intervention during the process can interrupt it.

- Any response must respect legitimate religious practice and individual human rights.

- A coordinated whole of government response is required to respond to the threat posed by radicalisation and extremism. Stakeholders from across society should be given the opportunity to contribute.

- The integration of immigrants into Irish communities, and the provision of educational and economic opportunities, will continue to be important in preventing feelings of alienation and deprivation.

Part Four will conclude the paper by drawing informed conclusions from the research findings and offering recommendations for how the state should seek to respond to the radicalisation of Irish citizens in support of Islamist terrorism. 


\title{
PART FOUR. Conclusions and Recommendations
}

\begin{abstract}
If radicalisation takes a foothold in the State, no matter what perspective or what context, whether it's Islamist, right-wing or left-wing, it will cause serious challenges, and tackling those challenges will be problematic because I don't see a proactive approach to dealing with it (Interviewee A, 2020).
\end{abstract}

\section{Introduction}

The aim of this research paper was to establish what steps the state should take to respond to the radicalisation of Irish citizens in support of Islamist terrorism. The review of literature answered the first and second subordinate research questions by examining models of radicalisation to identify behavioural and background indicators of radicalisation and analysing how these indicators are used operationally in the UK and Denmark as part of counter-radicalisation efforts. It was apparent from the review that the definition of radicalisation and three interconnected themes of the individual, the ideology, and the environment necessitated further analysis. The methodological approach adopted was outlined in Part Two, and analysis of the data collected was presented in Part Three. The responses of interviewees proposed a number of measures which the state can take to respond to Islamist radicalisation, thereby answering the final subordinate research question.

\section{Summary of Key Findings}

Throughout all interviews, it was apparent that there is a perception that the current approach to security is reactive in nature, does not serve the country well, and Ireland is demonstratively trailing European neighbours in this space. At the national level, the lack of publicly available policies and strategies to elucidate, guide and to specify how the state seeks to provide security and counter the specific issues of radicalisation illustrates an immaturity in the preparedness in the country. Documentary analysis of the counterterrorism and counter-radicalisation strategies published in the UK and Denmark, together with examinations of relevant literature in Part One demonstrates that publishing strategies has the potential to give clarity to an otherwise opaque issue, and can also generate debate and academic research. This, in turn, engenders greater confidence and trust in the measures taken.

Specific to the subject of radicalisation, the reactive nature of the Irish approach is underlined by the lack of a definition of radicalisation in use across government. The responses of interviewees illustrated a general agreement on the conceptualisation of radicalisation, but also drew divergent opinions in the key area of cognitive versus behavioural radicalisation. This is an important distinction which underlines the need for widespread consultation among experts prior to a definition being promulgated. It was suggested that the peculiar approach in Ireland could be attributed to a political calculation based on balancing the risks or rewards for pre-empting the likelihood of security issues and attracting the attention of the voting public. In any case, from this interview sample, and documentary research, there is a demonstrated desire for a more inclusive attitude to the measures taken to provide security in this country.

The level of awareness of the complexity of radicalisation, its individual nature, and effects of external factors such as ideological and religious influence shown by interviewees 
was high. Equally, the desire for widespread consultation from expert stakeholders prior to the formulation of a state response to Islamist radicalisation was clearly expressed. However, although the need for a whole-of-government approach was stressed, there was also a clear perception that the level of expertise to recognise and respond to suspected (or known) cases of radicalisation is unlikely to be available amongst the key stakeholders in the public service, including the civil service, An Garda Síochána, and the Irish Prison Service. Synthesising the findings from the literature with the responses of interviewees, it is apparent that indicator-driven models of radicalisation, such as those of Wiktorowicz (2004) and Precht (2007), are not yet proven as effective bases for identifying those at risk of radicalisation, given the individual nature of the process. They do, however, provide guidance against which to measure behaviour and as such are useful for generating discussion and providing the basis for training for front-line workers on how to identify the process of radicalisation in an individual.

A large number of measures were suggested which it was felt would improve the Irish state's response to Islamist radicalisation. Interviewees were clear that any response must avoid alienation and be conducted within an appropriate legal framework. Central to this is a whole of government approach, predicated upon a bespoke Irish strategy and the required level of training for key staff in An Garda Síochána, the Irish Prison Service, social workers, and other government agency staff. The need for the state to uphold its duty of care towards Irish citizens and to protect them from extremist views was expressed. The importance of encouraging the integration of migrants into the Irish community as a defence against extremist views and radicalisation was highlighted in this regard, as was the need for initiatives to provide educational and economic opportunities for migrants. The requirement for religious leaders to exercise a duty of care towards converts to Islam was also identified.

Finally, several risks were identified, including the risk of a poorly conceptualised response possibly alienating the Muslim community, which reverberates the risk versus reward issue raised above. However, the data collected revealed a clear appetite for a more proactive approach to Islamist radicalisation from the state.

\section{Recommendations}

The following recommendations are made as a result of this research which would inform and enhance the state's response to the radicalisation of Irish citizens in support of Islamist terrorism:

- Formulate and publish a comprehensive national strategy to counter the radicalisation of Irish citizens. A prudent first step would be the establishment of a group of experts, from the fields of security, social care, religious leaders, academic experts, and civil servants to adopt a definition of radicalisation in the Irish context. This will provide the basis for further measures, guided by the same group of experts.

- Raise the level of awareness of the general public to the dangers which radicalisation and extremist views pose towards Irish communities.

- Improve the level of coordination and communication, both within government and with non-governmental organisation, to facilitate timely responses to cases of radicalisation, which does not currently exist at this time.

- Continue to emphasise integration initiatives for migrants, to include the promotion of educational and economic opportunities. 


\section{Further Research}

Although this study set out to establish how Ireland should respond to Islamist radicalisation, it has also highlighted the perception that the state's approach to providing for security is under-developed. Further research of the state's approach to formulating policy and strategy relating to national security, and in particular to counter terrorism and radicalisation would be fruitful. The apparent rise of radicalisation in support of other political ideologies also represents an area worthy of further study.

\section{Conclusion}

The recommendations outlined above are modest in comparison with the approach adopted by other European countries but would represent an opportunity to change the approach for Ireland. Perhaps the prevailing attitude is fuelled by the belief that Ireland can continue to avoid being a high-profile target for Islamist terrorist groups, and therefore avoid tackling what can be a contentious issue politically and socially. However, there is no guarantee that we can continue to evade the threat of Islamist terrorism indefinitely. This study has found that a change of approach to radicalisation in this country is required; to do so would undoubtedly be challenging, however failing to do so could result in tragic consequences.

Please note that the views expressed in this article are those of the author alone and should not be taken to represent the views of the Irish Defence Forces, the Command and Staff School or any other group or organisation.

\section{BIBLIOGRAPHY}

Andregg, M. (2009) 'Intelligence Ethics, laying a foundation for the second oldest profession', in L. K. Johnson (Ed.), Handbook of Intelligence Studies. New York: Routledge, pp. 52-63.

Antonesa, M., Fallon, H., Ryan, A. B., Ryan, A., Walsh, T. \& Borys, L. (2006). Researching and Writing your Thesis: A Guide for Postgraduate Students. Maynooth: Maynooth Adult and Community Education.

AGS (2015) Annual Report: An Garda Síochána 2015, An Garda Síochána (online), Retrieved from: $\quad$ https://www.garda.ie/en/about-us/publications/annual\%20reports/an-gardasiochana-annual-reports/2015-annual-report-revised.pdf [Accessed 03 May 2020].

AGS (2016) Annual Report: An Garda Síochána 2016, An Garda Síochána (online), Retrieved from: https://www.garda.ie/en/about-us/publications/annual\%20reports/2016-annualreport.pdf [Accessed 03 May 2020].

AGS (2017) Annual Report: An Garda Síochána 2017, An Garda Síochána (online), Retrieved from: $\quad$ https://www.garda.ie/en/about-us/our-departments/office-of-corporatecommunications/news-media/2017-garda-annual-report.pdf [Accessed 03 May 2020].

AGS (2018) Annual Report: An Garda Síochána 2018, An Garda Síochána (online), Retrieved from: $\quad$ https://www.garda.ie/en/about-us/publications/annual\%20reports/an-gardasiochana-annual-reports/garda-annual-report-2018.pdf [Accessed 03 May 2020].

An Garda Síochána (2019a) Our Departments, Security and Intelligence, An Garda Síochána (online), Retrieved from: https://www.garda.ie/en/About-Us/Our-Departments/Securityand-Intelligence1/ [Accessed 05 January 2020]. 
An Garda Síochána (2019b) Crime prevention, Community engagement, An Garda Síochána (online), Retrieved from: https://www.garda.ie/en/Crime-Prevention/Communityengagement/Community-Policing.html [Accessed 07 January 2020].

Awan, A., Hoskins, A., \& O'Loughlin, B., (2012) Radicalisation and Media: Connectivity and Terrorism in the New Media Ecology. London: Routledge.

Barrett, R. (2017, October) Beyond the Caliphate: Foreign fighters and the threat of returnees, The Soufan Center (online), Retrieved from: https://thesoufancenter.org/wpcontent/uploads/2017/11/Beyond-the-Caliphate-Foreign-Fighters-and-the-Threat-of-

Returnees-TSC-Report-October-2017-v3.pdf\#page=10 [Accessed 06 January 2020].

BBC (2019, 04 November) UK terrorism threat downgraded to 'substantial', BBC News (online), Retrieved from: https://www.bbc.com/news/uk-50293238 [Accessed 02 February 2020].

BBC (2020, 03 February) Streatham attack: Police search homes as attacker Sudesh Amman named, BBC News (online), Retrieved from: https://www.bbc.com/news/uk-51356447 [Accessed 03 February 2020].

Beresford, J. (2019, 18 July) Irish ISIS bride Lisa Smith says: 'You can't blame me for what the Islamic State done', Irish Post (online), Retrieved from: https://www.irishpost.com/news/irish-isis-bride-lisa-smith-says-cant-blame-islamic-statedone-169045 [Accessed 07 January 2020].

Borum, R. (2003) Understanding the terrorist mindset, in FBI Law Enforcement Bulletin, July 2003, 7-10.

Borum, R. (2011) Radicalization into violent extremism II: A review of social science theories, Journal of Strategic Security, 4(4), 7-36.

Butt, R. \& Tuck, H. (2014) European counter-radicalisation and re-radicalisation: A comparative evaluation of approaches in the Netherlands, Sweden, Denmark and Germany, London: Institute for Strategic Dialogue (online), Retrieved from: https://www.eukn.eu/fileadmin/Files/News/De-radicalisation final.pdf [Accessed 03 February 2020].

Carswell, S. (2019, 02 December) Lisa Smith's detention extended as solicitor says she has 'strong case', Irish Times (online), Retrieved from: https://www.irishtimes.com/news/crime-and-law/lisa-smith-s-detention-extended-assolicitor-says-she-has-strong-case-1.4101773 [Accessed 03 February 2020].

CFPI (2018, 18 September) The Future of Policing in Ireland, Commission on the Future of Policing in Ireland (online), Retrieved from: http://policereform.ie/en/POLREF/Pages/PB18000006 [Accessed 04 May 2020].

Choudhury, T. (2007) The role of Muslim identity politics in radicalisation: A study in progress, United Kingdom Department for Communities and Local Government, London (online), Retrieved from: https://www.academia.edu/1961790/The role of Muslim identity_politics in radicalis ation [Accessed 10 December 2019].

Connor, K. (2005) 'Islamism' in the West? The lifespan of Al-Muhajiroun in the United Kingdom, in Journal of Muslim Minority Affairs, 25(1), 117-133. 
Coolsaet, R. (Ed.) (2013) Jihadi terrorism and the radicalisation challenge: European and American experiences, $2^{\text {nd }}$ edition, Farnham, Surrey: Ashgate Publishing.

Coolsaet, R. (2015) What drives Europeans to Syria, and to IS? Insights from the Belgian case, Egmont - The Royal Institute for International Relations, Egmont Papers (online), Retrieved from: http://www.egmontinstitute.be/what-drives-europeans-to-syria-and-tois-insights-from-the-belgian-case/ [Accessed 07 January 2020].

Creswell, J.W. \& Poth, C. (2018) Qualitative inquiry \& research design: Choosing among five approaches ( $4^{\text {th }}$ ed.), California: SAGE Publications Ltd.

CSO (2016) Census of Population 2016 - Profile 8 Irish Travellers, Ethnicity and Religion, Central Statistics Office (Online), Retrieved from: https://www.cso.ie/en/releasesandpublications/ep/p-cp8iter/p8iter/p8rnc/ [Accessed 05 August 2019].

DFAT (2015, 11 June) Minister Flanagan addresses Seanad Éireann on Ireland's response to ISIS threat, Department of Foreign Affairs and Trade (online), Retrieved from: https://www.dfa.ie/news-and-media/press-releases/press-releasearchive/2015/june/irelands-response-to-isis-threat/ [Accessed 29 December 2019].

DOD (2015, 16 October), White Paper on Defence, Department of Defence (online), Retrieved from: https://www.gov.ie/en/policy-information/bee90a-white-paper-ondefence/ [Accessed 06 December 2019].

DOD (2019, 12 December), White Paper on Defence: Update 2019, Department of Defence (online), Retrieved from: https://www.gov.ie/en/publication/a519cf-white-paper-ondefence-update-2019/ [Accessed 07 August 2021].

DOJ (2017, 07 February) The Migrant Integration Strategy: A Blueprint for the Future, Department of Justice \& Equality (online), Retrieved from: http://www.justice.ie/en/JELR/Pages/Migrant Integration Strategy -

A Blueprint for the Future [Accessed 07 January 2020].

DOJ (2019a) Action Plan for the Joint Management of Offenders, 2019 - 2021, Department of Justice \& Equality (online), Retrieved from: http://www.justice.ie/en/JELR/Pages/actionplan-for-the-joint-management-of-offenders-2019-to-2020 [Accessed 03 May 2020].

DOJ (2019b, 12 March) Minister for Justice reply to Parliamentary Question 205, Department of Justice \& Equality (online), Retrieved from: http://www.justice.ie/en/JELR/Pages/PQ-12-03-2019-205 [Accessed 06 January 2020].

EUR-Lex (2017, 31 March) Directive (EU) 2017/541 on combatting terrorism, European Commission (online), Retrieved from: https://eur-lex.europa.eu/legalcontent/EN/TXT/?uri=CELEX\%3A32017L0541 [Accessed 06 January 2020].

European Commission (2020) Prevent strategies of member states, European Commission (online), Retrieved from: https://ec.europa.eu/home-affairs/what-wedo/networks/radicalisation_awareness network/ran-and-member-states/repository en [Accessed 28 January 2020].

Frey, B. (2018) The sage encyclopaedia of educational research, measurement, and evaluation, (Vol. 4), California: SAGE Publications Ltd. 
Gallagher, C. (2019, 14 December) Plan to be put in place over radicalisation risk, Irish Times (online), Retrieved from: https://www.irishtimes.com/news/crime-and-law/plan-to-beput-in-place-over-radicalisation-risk-1.4114830 [Accessed 06 January 2020].

Glaser, B. G. (1978). Theoretical Sensitivity: Advances in the Methodology of Grounded Theory. California: Sociology Press.

Government of Denmark (2014) Prevention of radicalisation and extremism action plan, Government of Denmark (online), Retrieved from: https://www.justitsministeriet.dk/sites/default/files/media/Pressemeddelelser/pdf/2015 /SJ20150422125507430\%20\%5BDOR1545530\%5D.PDF [Accessed 03 February 2020].

Government of Denmark (2016) Preventing and countering extremism and radicalisation: National action plan, Government of Denmark (online), Retrieved from: https://uim.dk/publikationer/preventing-and-countering-extremism-and-radicalisation [Accessed03 February 2020].

Hamlyn, D. (1995) 'Epistemology, history of', The Oxford Companion to philosophy, in T. Honderich (Ed.), Oxford: Oxford University Press, pp. 242-245.

Hardy, K. (2018) Comparing theories of deradicalization with Countering Violent Extremism Policy, Journal for Deradicalization, Summer 2018, 76-110.

Hoffman, B. (2006) Inside Terrorism. New York: Columbia University Press.

Horgan, J. (2008) From profiles to pathways and roots to routes: Perspectives on radicalisation into terrorism, The Annals of the American Academy of Political and Social Science, 618(1), 80-94.

Horgan, J. (2011) Remarks at START symposium, 'Lessons learned since the terrorist attacks of September 11, 2001', Washington D.C., 01 September 2011 (online), Retrieved from: http://www.c-spanvideo.org/program/TenYearA [Accessed 06 January 2020].

Hoskins, A. \& O'Loughlin, B. (2009) Media and the myth of radicalisation, Media, War and Conflict, 2(2), 107-110.

Hurley, D. (2018, 11 September) Combating terrorism and the potential challenges posed by EU Directive 2017/541, Oireachtas na hÉireann Library and Research Service (online), Retrieved from:

https://www.oireachtas.ie/en/publications/?q=note\%20541\&author\%5B\%5D=libraryresearchservice \&date=\&term=\%2Fie\%2Foireachtas $\% 2 F$ house $\% 2 F$ dail $\% 2 F 32 \&$ fromDate $=07 \% 2 \mathrm{F01}$ \%2F2020\&toDate=08\%2F01\%2F2020 [Accessed 21 December 2019].

ICSR (2012) Countering radicalisation in Europe, The International Centre for the Study of Radicalisation and Political Violence (online), Retrieved from: https://icsr.info/wpcontent/uploads/2012/12/ICSR-Report-Countering-Radicalization-in-Europe-1.pdf [Accessed 08 January 2020].

Independent (2020, 03 February) Streatham terror attack: ISIS claims responsibility for stabbing by supporter Sudesh Amman, Independent (online), Retrieved from: https://www.independent.co.uk/news/uk/crime/streatham-terror-attack-isis-londonsudesh-amman-latest-a9314481.html [Accessed 03 February 2020]. 
Johansen, M. L. (2019) Epidemic policing: The spreading of counter-radicalization in Denmark, SAGE Journals, Environment \& Planning: Society \& Space (online), Retrieved from: $\quad$ https://journals-sagepub-com.jproxy.nuim.ie/doi/10.1177/0263775819864119 [Accessed 06 February 2020].

Keena, C. (2019, 12 January) From Ireland to Isis: The life of Alexandr Ruzmatovich Bekmirzaev, Irish Times (online), Retrieved from: https://www.irishtimes.com/news/crime-and-law/from-ireland-to-isis-the-life-ofalexandr-ruzmatovich-bekmirzaev-1.3753888 [Accessed 05 January 2020].

Kepel, G. (2016, 14 March) "Radicalizations" and "Islamophobia": The king is naked, Liberation (online), Retrieved from: https://www.liberation.fr/debats/2016/03/14/radicalisations-et-islamophobie-le-roi-estnu_1439535 [Accessed 08 January 2020].

Killock, J. (2019, 31 July) Informal internet censorship: The UK's Counter-Terrorism internet referral unit (CTIRU), Voxpol (online), Retrieved from: https://www.voxpol.eu/informalinternet-censorship-the-uks-counter-terrorism-internet-referral-unit-ctiru/ [Accessed 07 January 2020].

King, M. \& Taylor, D. (2011) The radicalization of homegrown jihadists: A review of theoretical models and social psychological evidence, in Terrorism and Political Violence, 23:4, 602-622.

King, N. \& Horrocks, C. (2010) Interviews in Qualitative Research. London: Sage.

Knefel, J. (2013, 06 May) Everything You've Been Told About Radicalisation Is Wrong, Rolling Stone Magazine, Retrieved from: https://www.rollingstone.com/politics/politicsnews/everything-youve-been-told-about-radicalization-is-wrong-80445/ [Accessed 07 August 2019].

Kühle, L. \& Lindekilde, L. (2010) Radicalisation among young Muslims in Aarhus, Centre for the Studies in Islamism and Radicalisation, Aarhus University (online), Retrieved from: https://www.ps.au.dk/fileadmin/site files/filer_statskundskab/subsites/cir/radicalization aarhus FINAL.pdf [Accessed 06 January 2020].

Kühle, L. \& Lindekilde, L. (2012) Radicalisation and the limits of tolerance: A Danish casestudy, Journal of Ethnic and Migration Studies, 38(10), 1607-1623.

Kundnani, A. (2012) Radicalisation: the journey of a concept, Race \& Class, 54(2), 3-25.

Lindekilde, L. (2012) Introduction: assessing the effectiveness of counter-radicalisation policies in Northwestern Europe, Critical Studies on Terrorism, 5(3), 335-344.

Lofland, J. \& Lofland, L. L. (1995) Analyzing Social Settings: A Guide to Qualitative Observation and Analysis (3rd ed.). California: Wadsworth.

Mandel, D. (2009) 'Radicalization: What does it mean?', in T. Pick, A. Speckhard \& B. Jaunch (Eds.), Homegrown terrorism: Understanding the root causes of radicalisation among groups with an immigrant heritage in Europe, Brussels: Institute of Physics Press.

Maynard, M. (1994) 'Methods, practice and epistemology: The debate about feminism and research' in Researching Women's Lives from a Feminist Perspective, M. Maynard, and J. Purvis (Eds.). London: Taylor \& Francis, pp. 10-26. 
McCauley, C. \& Moskalenko, S. (2008) Mechanisms of political radicalization: Pathways toward terrorism, in Terrorism and Political Violence, 20(3), 415-433.

McCauley, C. \& Moskalenko, S. (2011) Friction: How Radicalization Happens to Them and Us. New York: Oxford University Press USA.

McCauley, C. \& Moskalenko, S. (2017) Understanding political radicalisation: The two pyramids model, American Psychologist (Psychology of Terrorism), 72(3), 205-216.

McGarry, P. (2019, 07 January) Muslim leader criticises Varadkar's comments on Irish 'Isis terrorist', Irish Times (online), Retrieved from: https://www.irishtimes.com/news/socialaffairs/religion-and-beliefs/muslim-leader-criticises-varadkar-s-comments-on-irish-isisterrorist-1.3750365 [Accessed 06 January 2020].

McMahon, C. \& Kelly, L. (2016, 05 November) Irish jihadist known as Khalid Kelly dies in suicide attack - ISIS claims, Irish Independent (online), Retrieved from: https://www.independent.ie/world-news/war-on-terror/irish-jihadist-known-as-khalidkelly-dies-in-suicide-attack-isis-claims-35190395.html [Accessed 21 December 2019].

Moghaddam, F. (2005) The staircase to terrorism: A psychological exploration, American Psychologist, 60(2), 161-169.

Mulqueen, M. (2009) Re-evaluating Irish National Security Policy: Affordable threats? Manchester: Manchester University Press.

Neumann, P. (2008) Introduction to Perspectives on Radicalisation and Political Violence: Papers from the First International Conference on Radicalisation and Political Violence, London 17-18 January 2008 (London: International Center for the Study of Radicalisation and Political Violence, 2008), Retrieved from: https://www.nonviolent-conflict.org/wpcontent/uploads/2016/11/Perspectives-on-Radicalisation-Political-Violence.pdf

[Accessed: 07 January 2020].

Neumann, P. (2013) The trouble with radicalization, International Affairs (Royal Institute of International Affairs 1944-), 89(4), 873-893.

Nossiter, A. (2016, 12 July) 'That ignoramus' 2 French scholars of radical Islam turn bitter rivals, New York Times (online), Retrieved from: https://www.nytimes.com/2016/07/13/world/europe/france-radical-islam.html [Accessed 05 January 2020].

O'Donnell, A. (2016) Securitisation, counterterrorism, and the silencing of dissent: the educational implications of Prevent, British Journal of Educational Studies, 64(1), 53-76.

Oireachtas na hÉireann (2015, 16 July) Foreign Conflicts Dáil Éireann debate, 16 July 2015, Oireachtas na hÉireann (online). Retrieved from: https://www.oireachtas.ie/en/debates/question/2015-07-16/411/ [Accessed 06 August 2019].

Oireachtas na hÉireann (2018, 23 May) Foreign Conflicts Dáil Éireann debate, 23 May 2018, Oireachtas na hÉireann (online), Retrieved from: https://www.oireachtas.ie/en/debates/question/2018-05-23/70/\%23pq 70 [Accessed 02 February 2020]. 
Oireachtas na hÉireann (2019, 25 June) International Terrorism Dáil Éireann debate, 25 June 2019, Oireachtas na hÉireann (online), Retrieved from: https://www.oireachtas.ie/en/debates/question/2019-06-25/261/ [Accessed 02 February 2020].

O'Keeffe, C. (2019, 06 December) New terror laws still hit by delays, Irish Examiner (online), Retrieved from: https://www.irishexaminer.com/breakingnews/ireland/new-terror-lawsstill-hit-by-delays-968758.html [Accessed 06 January 2020].

Paul, A. et al. (2017) The challenge of jihadist radicalisation in Europe and beyond, European Policy Centre, Brussels (online), Retrieved from: https://www.epc.eu/en/Publications/TheChallenge-of-Jihadist-Radicalisation--In-Europe-and-Beyond 20ebbc [Accessed 07 January 2020].

Precht, T. (2007) Home grown terrorism and Islamist radicalisation in Europe: From conversion to terrorism, Danish Ministry of Justice (online), Retrieved from: https://www.justitsministeriet.dk/sites/default/files/media/Arbejdsomraader/Forskning/ Forskningspuljen/2011/2007/Home grown terrorism and Islamist radicalisation in Eur ope - an assessment of influencing factors 2 .pdf [Accessed 05 January 2020].

Ragazzi, F. (2017) Countering terrorism and radicalisation: Securitising social policy? Critical Social Policy, 37(2), 163-179.

Reynolds, P. (2019, 12 January) The Irish who are fighting for ISIS, RTE.ie (online), Retrieved from: https://www.rte.ie/news/2019/0112/1022775-paul-reynolds-the-irish-who-arefighting-for-isis/ [Accessed 05 January 2020].

Richards, A. (2015) From terrorism to 'radicalization' to 'extremism': counterterrorism imperative or loss of focus? International Affairs, 91(2), 371-380.

Robson, C. (2011) Real World Research (3 ${ }^{\text {rd }}$ ed.). Chichester: Wiley.

Ryan, A. B. (2015) Methodology: Collecting Data, in Walsh, T., and Ryan, A. (Eds.) Writing your thesis: A guide for postgraduate students. Maynooth: MACE.

Sabir, R. (2017) Blurred lines and false dichotomies: Integrating counterinsurgency into the UK's domestic 'war on terror', Critical Social Policy, 37(2), 202-224.

Schmid, A. (2013) Radicalisation, De-Radicalisation, Counter-Radicalisation: A Conceptual Discussion and Literature Review. The Hague: ICCT Research Paper.

Schmid, A. (2016) Research on radicalisation: Topics and themes, Perspectives on Terrorism, 10(3), 26-32.

Sedgwick, M. (2010) The concept of radicalisation as a source of confusion, Terrorism \& Political Violence, 22(4), 479-494.

Silke, A. (2008) Research on terrorism: A review of the impact of 9/11 and the Global War on Terrorism, in Chen, H., Reid, E., Sinai, J., Silke, A., Ganor, B. (Eds.) Terrorism Informatics: Knowledge Management and Data Mining for Homeland Security. New York: Springer, pp. 27-50.

START Global Terrorism Database (2019), Background Report: Global Terrorism in 2018, National Consortium for the Study of Terrorism and Responses to Terrorism (START), University of Maryland (online), Retrieved from: 
https://www.start.umd.edu/sites/default/files/publications/local_attachments/START_G TD Terrorismln2018_Oct2018.pdf [Accessed 13 October 2019).

Statistics Denmark (2020) Population in Denmark, Statistics Denmark (online), Retrieved from: $\quad$ https://www.dst.dk/en/Statistik/emner/befolkning-og-valg/befolkning-ogbefolkningsfremskrivning/folketal [Accessed 05 February 2020].

Taylor, J. (2018) 'Suspect Categories,' alienation and counterterrorism: Critically assessing PREVENT in the UK, Terrorism and Political Violence,

UK Government (2011) Prevent Strategy Review, HM Government (online), Retrieved from: https://assets.publishing.service.gov.uk/government/uploads/system/uploads/attachme nt_data/file/97976/prevent-strategy-review.pdf [Accessed 15 December 2019].

UK Government (2018) CONTEST: The United Kingdom's strategy for countering terrorism, HM Government (online), Retrieved https://www.gov.uk/government/publications/counter-terrorism-strategy-contest-2018 [Accessed 02 January 2020].

UK Government (2019, 10 April) Revised Prevent duty guidance: For England and Wales, HM Government (online), Retrieved https://www.gov.uk/government/publications/prevent-duty-guidance/revised-preventduty-guidance-for-england-and-wales [Accessed 07 January 2020].

Vidino, L. \& Brandon, J. (2012) Countering radicalisation in Europe, The International Centre for the Study of Radicalisation and Political Violence (online), Retrieved from: [Accessed 05 January 2020].

Vidino, L. (2013) European strategies against jihadist radicalisation, CSS Analysis in Security Policy NO. 128, ETH Zurich (online), Retrieved from: https://www.researchcollection.ethz.ch/bitstream/handle/20.500.11850/65182/1/eth-7378-01.pdf [Accessed 06 February 2020].

Wiktorowicz, Q. (2004) Joining the Cause: Al-Muhajiroun and Radical Islam, paper presented at The Roots of Islamic Radicalism Conference (Yale University, 2004), Retrieved from:

https://securitypolicylaw.syr.edu/wpcontent/uploads/2013/03/Wiktorowicz.Joining-the-Cause.pdf [Accessed 07 January 2020].

Yin, R. (2009) Case study research: Design and methods ( $4^{\text {th }}$ ed.), California: SAGE Publications Ltd. 